Trade Liberalization and the Gender Employment Gap in China

Feicheng Wang, Krisztina Kis-Katos, Minghai Zhou

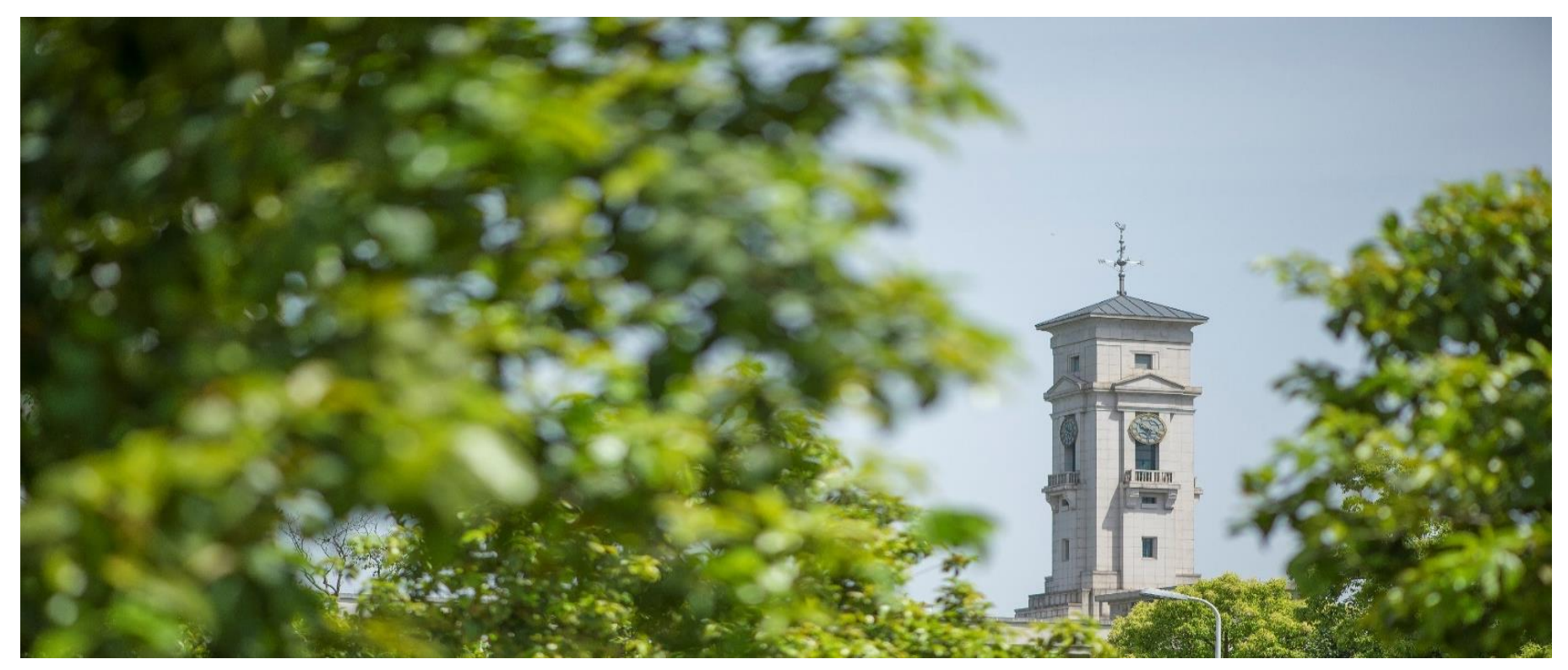


Faculty of Humanities and Social Science, University of Nottingham Ningbo China, 199 Taikang East Road, Ningbo, 315100, Zhejiang, China.

First published 2020

This work is made available under the terms of the Creative Commons Attribution 4.0 International License:

http://creativecommons.org/licenses/by/4.0

The work is licenced to the University of Nottingham Ningbo China under the Global University Publication Licence:

https://www.nottingham.edu.cn/en/library/documents/researchsupport/global-university-publications-licence-2.0.pdf 


\section{\begin{tabular}{l|l}
11 & $\begin{array}{l}\text { The University of } \\
\text { Nottingham }\end{array}$
\end{tabular}}

UNITED KINGDOM • CHINA • MALAYSIA

\section{UNNC School of Economics Working Paper Series}

Series G Globalisation and Economic Policy

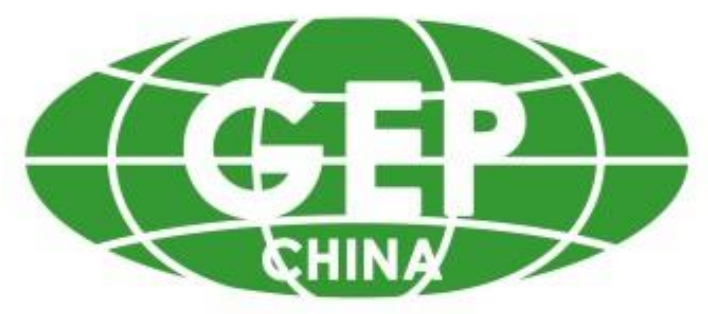

\section{Trade Liberalization and the Gender Employment Gap in China}

Feicheng Wang, Krisztina Kis-Katos, Minghai Zhou

School Economics Working Paper - GEP Series 2020.11G

(C) 2019 by Author names. All rights reserved. Short sections of text, not to exceed two paragraphs, may be quoted without explicit permission provided that full credit, including $\subset$ notice, is given to the source. 


\title{
Trade Liberalization and the Gender Employment Gap in China*
}

\author{
Feicheng Wang; ${ }^{\dagger}$ Krisztina Kis-Katos; ${ }^{\ddagger}$ Minghai Zhou ${ }^{\S}$
}

August 2020

\begin{abstract}
This paper investigates the impact of import liberalization induced labor demand shocks on male and female employment in China. Combining data from population and firm censuses between 1990 and 2005, we relate prefecture-level employment by gender to the exposure to tariff reductions on locally imported products. Our empirical results show that increasing import competition has kept more females in the workforce, reducing an otherwise growing gender employment gap in the long run. These dynamics were present both in local economies as a whole and among formal private industrial firms. Examining channels through which tariff reductions differentially affect males and females, we find that trade-induced competitive pressures contributed to a general expansion of female-intensive industries, a shift in sectoral gender segregation, reductions in gender discrimination in the labor market, technological upgrading through computerization, and general income growth.
\end{abstract}

Keywords: Trade liberalization; Import competition; Gender employment gap; China JEL classification: F13, F14, F16, F66, J16

\footnotetext{
${ }^{*}$ We are grateful to seminar and conference participants at University of Bonn, Beijing Normal University, University of Nottingham Ningbo China, 2019 Conference on the Economic Consequences of Trade, Finance and FDI in Beijing, ETSG 2019 in Bern, 2019 International Symposium on Contemporary Labour Economics in Shenzhen, and the 12th International Conference on the Chinese Economy in Clermont-Ferrand for valuable discussions and comments. We would also like to thank Matthew Rudh for his excellent assistance in proofreading the paper. All remaining errors are ours.

${ }^{\dagger}$ Department of Economics, University of Göttingen. Platz der Göttinger Sieben 3, 37073, Göttingen, Germany. Email: feicheng.wang@uni-goettingen.de.

${ }_{\ddagger}^{\ddagger}$ Department of Economics, University of Göttingen, and IZA, Bonn. Platz der Göttinger Sieben 3, 37073, Göttingen, Germany. E-mail: krisztina.kis-katos@uni-goettingen.de.

§School of Economics, University of Nottingham Ningbo China. 199 Taikang East Road, Ningbo 315100, China. Email: minghai.zhou@nottingham.edu.cn.
} 


\section{Introduction}

Since the 1990s, China has substantially opened up its goods market to global trade. Accompanied by several other additional market reforms, trade liberalization has had a major impact on the Chinese economy, contributing to rising firm-level productivity (Yu, 2015; Brandt et al., 2017), lower markup dispersion ( $\mathrm{Lu}$ and $\mathrm{Yu}, 2015)$, increased wage inequality and skill premiums (Han et al., 2012; Chen et al., 2017; Xu, 2019), and household adjustments of labor supply, saving, and co-residence (Dai et al., 2018), among other things. A few recent studies have also documented both substantial job creation and job destruction within the manufacturing sector due to China's trade liberalization policies (Ma et al., 2015; Rodriguez-Lopez and Yu, 2017). Yet less is known about the long-run and gender-specific effects of globalization, especially in combination with the economy-wide dynamics of market reforms. ${ }^{1}$

Before its entry into the World Trade Organization (WTO), China's employment rates were historically high and did not differ substantially by gender. At the time of the 1990 Population Census of China, about 90.3 percent of prime working-age males (15-50 years old) and 84.8 percent of females of the same age were employed. Transformation towards a market economy has led to larger declines in the employment rates of females than of males, leading to the emergence of a more substantial gender employment gap (see Figure A.1 in the Appendix, also documented by $\mathrm{Chi}$ and $\mathrm{Li}$ 2014). In this paper, we address to what extent trade liberalization policies contributed to gender-specific employment trends and the growing gender employment gap.

Regions more exposed to import competition can be expected to experience larger adjustments in their local labor markets. Labor demand will decline if important local import-competing firms face negative price shocks and reduce production. But labor demand can also increase if competitive pressures lead to factor substitution towards labor, or if technological upgrading increases demand for complementary workers (Bloom et al., 2016). Moreover, lower tariff rates on intermediate inputs improve access to a larger variety of intermediate goods, directly increasing firm productivity and employment (Goldberg et al., 2010). At the same time, labor supply may decrease because of increased incentives to invest in higher education among younger cohorts (Li, 2018; Li et al., 2019), or it may adjust because of changing average household incomes (Dai et al., 2018) and reservation wages. By focusing on local labor markets, we are able to assess the effects of predominantly demand-side factors on changes in the Chinese gender employment gap over time.

The labor market effects of trade liberalization could be gender-specific for a variety of reasons. From the demand side, trade-induced competition could reduce taste-based discrimination and increase the relative demand for female workers (Becker, 1957; Black and Brainerd, 2004; Hirata and Soares, 2016). Firms may also increase investments in technology as a response to import competition (Bloom et al., 2016). If computerization and technological upgrading reduce the demand for physical strength, which was once the primary comparative advantage for male

\footnotetext{
${ }^{1}$ Chen et al. (2013) and Dai et al. (2018) are two exceptions, with the former considering gender differences within exporting firms descriptively, and the latter focusing on within-household adjustments to import competition in the short run.
} 
workers, females' position in the labor market may improve (Juhn et al., 2014). Additionally, if social norms or individual preferences lead to sustained sectoral gender segregation in the workforce, trade-induced structural change will also lead to gender-specific shifts in labor demand. Under these conditions, the expansion of female-intensive sectors may increase the demand for female workers relative to male workers (Gaddis and Pieters, 2017; Kis-Katos et al., 2018), but may also reduce females' relative employment if male workers migrate from male-intensive to female-intensive sectors (Sauré and Zoabi, 2014). Finally, from the supply side, females' decisions to enter the labor market will also depend on shifts in household income (Klasen and Pieters, 2015; Klasen, 2019).

In our empirical analysis, we use the local labor market approach to uncover the differential adjustments of male and female workers following trade liberalization within Chinese prefectures in a long-difference setting, focusing mainly on changes from 1990 to 2005. This approach relies on a shift-share measure (Bartik, 1991) that combines industry-level variation in tariff rate reductions with differences in initial sectoral labor market composition across prefectures, and relates changes in local labor market outcomes to regionalized measures of tariff changes. ${ }^{2}$ We measure prefecture-level employment based on locally representative individual data from two waves of the population census (1990 and 2005). As a complementary source of information, we also use firm-level data from the 1995 industrial census and the 2004 economic census. The approach assumes limited worker mobility across regions, while allowing for worker reallocation across sectors within each region. The assumption partially holds in the Chinese context, in which the household registration system resulted in substantial migration barriers across regions, at least before 2005 (Meng, 2012). Nonetheless, we also show that our results persist when focusing on non-migrants only.

Our results indicate that while employment rates declined considerably for both men and women over time, the reduction in import tariffs kept relatively more females within the labor force, mitigating increases in the gender employment gap. These effects were present among both high-skilled and low-skilled workers, and among all age cohorts except for the youngest (15-25 years old), who experienced an educational expansion during the same time period. We find similar patterns for the formal industrial sector, but clear heterogeneity between stateowned enterprises (SOEs) and private enterprises. While workers tended to move from SOEs to private enterprises overall, this process was accelerated by the competitive pressures arising from import competition. Although private industrial firms hired more males than females on average, they responded to import competition by increasing female employment, which reduced the gender employment gap.

The gender effects of trade liberalization in China arose through various channels. First, we find evidence that import tariff reductions expanded sectors which were originally more femaleintensive, while at the same time reducing within-firm discrimination, measured by profit differentials between firms with differing numbers of female employees. Sectoral segregation by gender in the local employment market tended to decrease with tariff reductions, although it did not decrease significantly among formal industrial firms. All these factors may have contributed

\footnotetext{
${ }^{2}$ This approach has been widely used to examine the local labor market effects of tariff reductions (see e.g. Topalova, 2010, Kis-Katos and Sparrow, 2015, Dix-Carneiro and Kovak, 2017, and Li, 2018, among others).
} 
to a reduced gender employment gap. Second, we find evidence that computerization expanded more in private industrial firms which faced increasing import competition, but did not expand in the local economies on average. This result partially confirms the relevance of trade-induced technological upgrading. Finally, import tariff reductions were also linked to aggregate increases in economic activity, as proxied by nightlights. Thus, in the long run, we do not expect substantial negative income effects from import competition, at least not on average. Since females are more likely to exit the labor market than males with higher household incomes, aggregate income increases may have limited the decline in the gender employment gap; however, we do not find direct evidence to support this.

Our paper contributes to two main strands of the literature. First, we contribute to the growing body of literature on the labor market effects of trade liberalization in China (Ma et al., 2015; Rodriguez-Lopez and Yu, 2017; Dai et al., 2018) by focusing particularly on gender differentials in long-run employment dynamics and their potential causes. Our paper differs from these studies by not only considering formal manufacturing firms (like Ma et al., 2015; RodriguezLopez and Yu, 2017), but also by measuring employment within local labor markets. Since the size of the informal sector in China has surpassed the formal sector in recent years (Liang et al., 2016), and since informal workers may respond differently to trade liberalization (Ben Yahmed and Bombarda, 2020), extending the analysis beyond formal manufacturing firms helps us to measure the full impact of trade liberalization on employment. In contrast to Dai et al. (2018), we focus on a large set of prefectures instead of only fewer selected urban prefectures, as well as the long-run effects of tariff reforms instead of the effects of short-run, year-by-year tariff variations.

Second, we contribute to the literature studying the drivers of the gender gap in labor participation in developing countries in general, and the role of globalization in particular. Decreasing female labor force participation has been previously linked to urbanization (de Bruin and Liu, 2020), rising returns to education (Hare, 2016), increasing discrimination (Li and Song, 2013), higher costs of childcare and old age support (Maurer-Fazio et al., 2011), as well as changes in social norms (Hare, 2016; Chen and Ge, 2018). Studies on the gender effects of trade liberalization in developing countries document the role of import competition or export expansion for explaining changes in the gender gap in Brazil (Gaddis and Pieters, 2017), Indonesia (Kis-Katos et al., 2018), or Mexico (Juhn et al., 2014; Ben Yahmed and Bombarda, 2020).

While the existing studies rely solely on either individual-level labor census data, householdlevel survey data (Gaddis and Pieters, 2017; Kis-Katos et al., 2018; Ben Yahmed and Bombarda, 2020), or firm-level survey data (Juhn et al., 2014), this paper instead combines both large-scale population and firm census data, with the former capturing total employment adjustment within local regions and the latter reflecting employment adjustment within the formal industrial sector, thereby providing a more comprehensive and nuanced picture of labor market adjustments following trade liberalization.

Importantly, the firm-level census data allows for separate investigations into employment adjustments in state and private sectors, which have not yet been examined in the literature. The differential employment adjustments between state-owned and private enterprises following the tariff reductions imply that an expansion of the private sector has played an important role 
in shaping the gendered effects of trade liberalization. While our finding that tariff reductions reduced the gender employment gap is consistent with previous studies, we additionally test several possible channels against each other and hence contribute to a better understanding of why trade induced import competition affects males and females differently.

The remainder of this paper is organized as follows. In the next section, we present the institutional context and survey the evidence on the labor market effects of tariff reforms in China. Section 3 presents our data sources, reports descriptive statistics, introduces measures of regional exposure to tariff reductions, and describes the empirical strategy. Section 4 reports empirical results, section 5 examines potential channels, and section 6 concludes.

\section{Trade reforms and labor market adjustments in China}

Following its application for WTO membership in 1995, and in particular after its formal entry into the WTO in December 2001, China substantially reduced its import tariffs, fulfilling the majority of its tariff-reduction commitments by $2005 .^{3}$ As shown in Figure 1, there has been a strong convergence in tariff rates over time: average import tariff rates declined from over 40 percent in the early 1990s to 10 percent in 2005, and stayed fairly constant since then. These tariff reforms led to a substantial surge in imports, raising the competitive pressures on domestic import-competing firms but also improving access to imported inputs.

During this same time period, employment rates declined among both males and females, with larger declines among females, which led to a widening gender employment gap. Figure A.1 in the Appendix shows employment rates by gender among the full adult population according to ILO definitions (aged 15 years or older), whereas Table 1 reports employment rates in the working-age population according to Chinese definitions (aged 15 to 50 years) in 1990 and 2005. The employment rate of working-age males decreased from 90.4 percent to 81.9 percent from 1990 to 2005, and from 84.8 percent to 71.6 percent for females (see Table 1). Employment declines resulted in only slight increases in the unemployment rate and were mostly linked to an increase in the non-participation rate, especially among the younger cohorts. Employment rates fell most strongly among the youngest cohort (15 to 25 years old), with similar average dynamics among both genders. In contrast, the male-female employment gap increased the most among the 26-35 year old cohort, which are among the primary child-bearing age, and could also reflect rising household incomes (Hare, 2016) or higher costs of child-rearing (Maurer-Fazio et al., 2011).

A rapidly expanding body of empirical literature documents the substantial labor market effects of the increasing import competition in China. Trade liberalization has simultaneously induced job creation and job destruction, resulting in net job growth in the formal manufacturing sector (Ma et al., 2015). Import competition-induced job destruction was concentrated in lowproductivity firms, while high-productivity firms created additional jobs (Rodriguez-Lopez and $\mathrm{Yu}, 2017)$. In the short run, import competition also led to wage declines in urban households, who responded by increasing household labor supply, depleting assets, and pursuing other strategies of cost-cutting (Dai et al., 2018).

\footnotetext{
${ }^{3}$ http://www.china.org.cn/government/whitepaper/node_7143951.htm
} 
Import tariff reductions capture only one dimension, albeit an important one, of trade liberalization. During our period of analysis, China underwent a whole series of further trade policy-related reforms, all of which may confound the employment effects of import tariff reductions. As part of its trade policy reforms following its accession to the WTO, China also reduced non-tariff barriers (NTBs), further opening the domestic market for imports. China also lowered its foreign direct investment (FDI) restrictions, which may have particularly benefited females by bringing less discriminatory gender norms (Juhn et al., 2014; Tang and Zhang, 2017). Descriptive evidence also shows that in 2004 foreign-invested firms (as well as exporters) had on average a higher share of female workers than domestic non-exporters did (Chen et al., 2013). China's WTO accession also brought about considerable improvements in its export market access. Starting in 2000, China received permanent Normal Trade Relations (NTR) status from the U.S., which reduced tariff uncertainties and led to increased exports (Pierce and Schott, 2016). Increases in labor demand led to additional migration inflows in prefectures that experienced a larger decline in this tariff uncertainty (Facchini et al., 2019). Finally, improving export market access towards all potential trading partners in general has also been shown to shift patterns of human capital accumulation (Li, 2018). In sensitivity tests, we will control for all these alternative dimensions of globalization-related policy reforms.

\section{Data sources and empirical strategy}

\subsection{Data sources}

We measure local employment by gender primarily based on the 1990 and 2005 waves of the population census. The former is a 1 percent random sample obtained from IPUMSInternational (Minnesota Population Center, 2019), while the latter comes from the National Bureau of Statistics (NBS) of China. ${ }^{4}$ The long-difference analysis of changes over 15 years allows us to capture the long-run employment effects of trade liberalization. The two waves of the population census record individual information, including demographic characteristics, working status, industry, occupation, location of residence, and migration status. Since the 1990 population census does not directly report an individual's working status but rather reports their industry and occupation, we identify an individual as being employed if either the industry or the occupation code is not missing. The census waves also report on other full-time activities, categorized as education, retirement, disability, or housework. This further helps to identify employment status.

The 1 percent random sample of the 1990 population census and the 2005 mini-census are representative at the level of Chinese prefectures, which can be considered as representing local labor markets. More importantly, they include both formal and informal employment in all sectors, and hence show a more complete picture of the labor market. They also report detailed industrial classifications at the individual level, which help to detect variations in

\footnotetext{
${ }^{4}$ The 2005 wave is a mini-census that covers 1 percent of the population. The reason why we do not use the 2000 population census, although available, is that tariff changes between 2000 and 2005 were not necessarily exogenous since import tariffs had already reduced endogenously and remarkably even before China's accession to the WTO.
} 
industry composition across regions so as to precisely measure regional exposures to changing tariff rates. ${ }^{5}$ For the local labor market analysis, we aggregate individual-level data to the prefecture level. We constrain our sample to the working-age population, defined as the age group between 15 and 50, in order to make males and females comparable, since the compulsory retirement age is 50 for women, 10 years less than that of men.

We complement the population census waves with firm-level data from the 1995 industrial census and the 2004 national economic census, both collected by the NBS China. The former covers all industrial firms operating in manufacturing and mining, while the latter covers all firms economy-wide, which we restrict to the industrial sample. The firm census reports detailed information on firm-level activities, including the number of male and female workers within firms, four-digit industry codes, and geographical location. As before, we aggregate firm-level data to the prefecture level of local labor markets. Compared with the population census, the firm-level data allow us to explore heterogeneous effects on firms by different ownership types, and therefore to investigate how privatization dynamics interacted with the effects of globalization.

Further controls on local trade policy exposure are obtained from Brandt et al. (2017) and Facchini et al. (2019). Industry-level data on NTBs and FDI restrictions have been provided by Brandt et al. (2017). A further set of prefecture-level controls, including regional exposure to measures of the NTR tariff gap (used to proxy market access to the U.S.), export licensing requirements and the average government subsidy to exporters are taken from Facchini et al. (2019). ${ }^{6}$ Nightlight data are derived from National Oceanic and Atmospheric Administration (NOAA) and nightlights at the prefecture level are calculated as the simple average of all pixel values within the boundary of each prefecture (Liao and Fei, 2019).

Concordant administrative codes for prefectures between 1990 and 2005 yield 322 prefectures in total. We exclude seven prefectures with incomplete data, ${ }^{7}$ and four further prefectures in which more than 75 percent of the local population worked in non-tradable sectors in 1990, which makes the assumption of a perfect pass-through from the tradable to non-tradable sectors less likely to hold (Kovak, 2013). This yields a final sample of 311 Chinese prefectures. See Table A.1 in the Appendix for descriptive statistics on the main dependent variables and controls, expressed as changes from 1990 to 2005, complemented by initial conditions in 1990 .

\subsection{Measuring regional tariffs and other trade policies}

We build our main explanatory variable using tariff information from the World Integrated Trade Solution (WITS). We obtain China's import tariff rates at HS 6-digit level (for 5,224 products) over the period between 1992 to $2005 .{ }^{8}$ We calculate import tariffs at the level of 162

\footnotetext{
${ }^{5}$ The 1990 population census reports 328 3-digit Chinese industries.

${ }^{6}$ Facchini et al. (2019) provide prefecture-level data on all measures in 1999 and 2005. Given that 1999 is still before China's accession to the WTO, we use these shorter-term changes as proxies for long-run changes for the purpose of robustness checks.

${ }^{7}$ These seven prefectures are all in the Tibetan region and are excluded due to missing data of control variables.

${ }^{8}$ China's earliest import tariff rates are available starting in 1992, which we use as the initial tariff year for our analyses.
} 
tradable sectors (available in the population census 1990) as the simple average of all products within sector $s$. We combine tariffs on agriculture, and the industrial sectors (mining and manufacturing) and decompose this measure for further robustness checks.

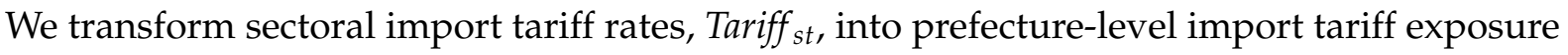
by weighting import tariff rates in each sector $s$, using the initial level of sectoral employment share within prefectures as weights:

$$
\operatorname{Tariff}_{p t}=\sum_{s=1}^{S} \frac{E_{s p, 0}}{E_{p, 0}} \operatorname{Tariff}_{s t}
$$

where Tariff ${ }_{p t}$ denotes import tariff exposure in prefecture $p$ in year $t, E_{s p, 0} / E_{p, 0}$ is the employment share of tradable sector $s$ over total tradable employment in prefecture $p$ during the initial year of the sample. Focusing only on the tradable sector relies upon the assumption that changes in the prices of tradable goods pass through to the local nontradables (Kovak, 2013).

The employment weighted import tariff adjustments exhibit substantial regional variation. Following China's WTO accession, prefectures that were most affected by import tariff reductions (at the 95th percentile) experienced a reduction of 35.5 percentage points, whereas in the least affected prefectures (at the 5th percentile) reductions amounted to about 25.0 percentage points (see Table A.2 in the Appendix). Figure A.2 in the Appendix displays the geographical distribution of tariff reductions between 1992 and 2005. Southeastern prefectures experienced larger tariff reductions on average than northwestern ones, reflecting a concentration of industries more heavily exposed to tariff reduction in southeastern prefectures. The large geographical variation in exposure to tariff reductions will contribute to identifying the employment effects of trade liberalization in China.

For robustness checks, we include a series of further trade policy measures at the prefecture level, all of which rely on a similar procedure as equation (1), using initial sectoral employment shares to weight sectoral exposure to other trade policies (obtained from Brandt et al. 2017 and Facchini et al. 2019). We measure regional export tariff exposure by first computing a weighted average of all foreign tariff rates for each product (based on WITS), using the share of each potential trading partner's Gross Domestic Product (GDP) in world GDP as relative weights, and then combining product-level tariff rates into a regional measure as in equation (1).

\subsection{Empirical model}

To estimate the long-run effect of trade liberalization on employment rates in China, we regress the long difference in employment rates on tariff rate changes across prefectures using the following specification:

$$
\Delta Y_{p}=\alpha+\beta \Delta \operatorname{Tariff}_{p}+\mathbf{X}_{p, 0}^{\prime} \boldsymbol{\Gamma}+\varepsilon_{p}
$$

where $\Delta Y_{p}$ denotes the prefecture-level change in a variety of labor market outcomes from 1990 to 2005 when calculated from the population census data and from 1995 to 2004 when based on the formal industrial firm data. As our main dependent variables, we focus on male and female 
employment rates, further distinguished by age, skill, and firm ownership type. $\Delta$ Tariff $_{p}$ is the percentage point change in import tariff rate exposure. Our coefficient of interest, $\beta$, measures the impact of tariff rate reductions on employment rates. When distinguishing employment by gender, we always estimate the regressions on male and female employment jointly, in a seemingly unrelated regression framework, allowing for correlated (and robust) error terms. This allows us to statistically test the difference between tariff coefficients for male and female workers, which link to the gender employment gap directly.

Causal identification in this setting relies on prefectures being exogenously exposed to trade liberalization, with differences in the effects of trade arising from variations in initial economic structure. The first difference specification controls for all prefecture-level time-invariant characteristics that may affect average labor market outcomes. For instance, it captures spatial variation in social norms with respect to women's roles as homemakers, which varies strongly by geographic location (Chen and Ge, 2018). However, if there are unobserved factors simultaneously correlated with both exposure to tariff reductions and employment dynamics, our estimates will be biased. Endogeneity concerns may arise from two main sources. First, employment dynamics may be determined by other initial economic conditions (e.g., the size of the non-tradable sectors) that happen to be correlated with the initial industrial structure. Second, local exposure to tariff reductions may be spuriously correlated with a series of further policy changes.

We deal with the first concern by introducing a set of initial conditions in our baseline specifications, $\boldsymbol{X}_{p, 0}$, which account for sources of spatial differences in labor market dynamics. They include employment shares in the agriculture and tertiary sectors, which capture the local size of the non-industrial and non-tradable sectors. Since China's large scale privatization reform in the late 1990s led to substantial lay-offs of workers, with considerable gender differences in layoffs (Li and Song, 2013), we control for the initial employment share of SOEs to account for the scope for the reform in the local labor market. To proxy for initial differences in economic development, we use the regional intensity of nightlights in 1990 as a further control. In each regression, we also control for the initial level of the dependent variable to allow prefectures with different initial employment rates to follow different dynamics (Juhn et al., 2014). Initial female employment rates ranged from 26.1 percent in Ningde Prefecture to 97.5 percent in Diqing Tibetan Autonomous Prefecture according to the 1990 population census, resulting in very different potentials for adjustment in female employment. Descriptively, prefectures with a higher initial share of female employment were also more exposed to tariff reductions, since female-intensive industries—e.g., textiles, clothing and apparel—were both relatively low in skill intensity and also more protected (see Figure A.3).

We address the second concern by performing several robustness checks controlling for a series of further globalization-driven policy changes that may be correlated with the prefectures' exposure to import tariff reductions. Those variables include changes in regional exposure to NTBs, export tariffs, NTR tariff gaps, subsidies to exporters, export licenses, and FDI restrictions.

Since tariff rate reductions are designed at the industry level and regional tariff rates are calculated by re-weighting industry tariffs, the political economy of industry-level tariff setting could also raise endogeneity concerns. Politically powerful industries may lobby the 
government and seek for more protection (Goldberg and Pavcnik, 2005), which would result in prefectures dominated by such industries experiencing lower tariff rate reductions, at least in the short run. However, the nature of China's trade liberalization left little room for lobbying, as the target level of tariff rate reductions was pre-determined by the WTO negotiations such that initially more protected industries experienced substantially larger tariff reductions (Brandt et al., 2017). Hence, only the initial level of protection is likely to reflect political economy considerations, whereas the overall tariff reductions over 15 years can be considered to be fully determined by initial tariff levels. This is also supported by our tariff data. Initial import tariff rates in 1992 and tariff reductions between 1992 and 2005 at the 3-digit industry level are perfectly collinear (cf. Figure A.4, left panel), implying strong convergence in tariff rates across industries. The right panel of Figure A.4 shows a similar pattern at the prefecture level, i.e., prefectures with a higher initial level of tariff rates experienced a larger decline. We also check the robustness of our results using the initial tariff rates as an instrumental variable for tariff reductions (Goldberg and Pavcnik, 2005), which does not change our baseline results. Moreover, controlling for the initial share of SOEs will also proxy for political connections at the prefecture level. As SOEs are often closely connected to the government, they are more likely to lobby for regulatory exemptions which potentially go beyond the effects of tariff reductions.

\section{Results}

\subsection{Baseline results}

Table 2 shows the gender-specific employment effects of trade liberalization by estimating equation (2), using the changes in employment rates (in total and by gender) in the prefectures as dependent variables. The models control for a set of initial conditions, including the initial value of the dependent variable, as well as initial values of employment shares in the agriculture and tertiary sectors, the employment share of SOEs, and nightlights, all measured in 1990 (see Table A.3 in the Appendix for full results).

In terms of descriptive trends within our sample, employment rates among the working-age population declined by about 10 percentage points over the 15 years period, with females experiencing a 4.6 percentage points larger reduction than males. The estimated import tariff coefficient is negative in the full sample (in column 1), indicating that larger exposure to import tariff reductions resulted in smaller decreases in local employment. This average effect masks substantial differences by gender. Column 2 shows that male employment rates did not significantly respond to import tariff reductions, whereas female employment increased more substantially with import trade liberalization (column 3). The difference between female and male coefficients in the last column shows the extent to which import tariff reductions contributed to a changing gender employment gap. The difference in tariff coefficients amounts to 0.2 , and is statistically significant at the 5 percent level. In a prefecture that has experienced average tariff reductions, the employment gap between males and females is reduced by about 6.0 percentage points $(-30.09 \times 0.20=-6.02$, see Table A.1). The gender employment gap increased by 4.6 percentage points during the same time period, and so the contribution of 
import tariff reductions to reductions in the gender employment gap is economically sizable. Table 3 reports regressions separately by age cohort and skill level, distinguishing between the youngest cohort (aged 15 to 25), and two older cohorts (aged 26 to 35 and 36 to 50) as well as between low-skilled workers (who did not complete high school) and high-skilled workers. In terms of descriptive trends, the youngest cohort experienced very substantial declines in employment rates of about 27 to 29 percentage points. This trend reflects a substantial increase in tertiary education following the college expansion reform in the late 1990s (Ou and Zhao, 2016), which also increased upper-secondary enrolment and substantially delayed labor market entry among the youngest cohort. Among most of the older cohorts, employment rates declined by about 4 to 5 percentage points on average, with a somewhat larger decline among females of prime childbearing age ( 26 to 35 years old) of 10.8 percentage points. When differentiating by skill category, male employment rates among low-skilled workers fell by 8.8 percentage points, while female employment rates among low-skilled workers fell by 12.6 percentage points; these figures were 7.5 percentage points and 15.6 percentage points, respectively, among high-skilled workers. This gender employment gap increased the most among the second cohort (26 to 35 years old) as well as among the high-skilled. These different gender dynamics may have also been partly induced by changes in female labor supply, since improving incomes in emerging economies often induce a drop in labor supply among females with family duties (Klasen, 2019).

The regression results in Panel A of Table 3 show that exposure to tariff reductions did not affect the youngest age group and hence our results on the gender gap are not driven by the large education expansion and employment declines within the youngest cohort. Results in Table A.4 in the Appendix indeed document significant increases in education shares of the young with increases in import competition, but not differences by gender. At the same time, the rising import competition counteracted the trends in employment declines among the older cohorts (in Panels B and C), increasing female employment by more than male employment, which reduced the gender employment gap among both older cohorts. Import competition seems to have affected low- and high-skilled workers on average to a relatively similar extent. Although employment by low-skilled females responded somewhat more strongly than that of high-skilled females, the effects of import competition on the gender employment gap are virtually the same between the two skill groups.

The period of trade liberalization in China was accompanied by a major shift in production from SOEs towards private firms. Our baseline results show that import trade liberalization decreased the gender employment gap in the local labor market. We complement these results by using data from the industrial census and the economic census to analyse whether changes in the formal industrial sector contributed to these dynamics. Our period of analysis becomes shorter due to data availability, since we focus on changes from 1995 to 2004 . During this time period, formal industrial employment decreased slightly for both genders, together with a marginal increase in the gender employment gap (see Table 4, Panel A). The regression results in Panel A are broadly comparable to the results on total prefecture employment based on the population census (Table 2), although increases in male employment in formal enterprises due to increasing market competition turn out somewhat larger and the gender difference turns insignificant. 
However, privatization dynamics reveal substantial heterogeneity of the employment effects of trade by gender. Parallel to improvements in global market access during the late 1990s and early 2000s, China also implemented an extensive privatization reform, which has led to closures of SOEs and a large number of lay-offs of workers formerly in state-employment (Chi and $\mathrm{Li}, 2014)$. We test whether this ownership reform has also interacted with trade liberalization by splitting formal employment by ownership status. From 1995 to 2004, SOE employment declined among both males and females, with somewhat larger declines among males. At the same time, employment expanded within private formal enterprises, with somewhat larger increases in male employment compared to female employment.

Regressions of employment shares on tariff changes in Panel B of Table 4 show that prefectures facing larger manufacturing import competition experienced larger reductions in SOE employment. Although only the female coefficients are statistically significant, import competition-induced decreases in male and female SOE employment are not distinguishable from each other. At the same time, the competitive pressures arising from trade liberalization have contributed to the employment expansion of private enterprises. Interestingly, among private formal firms, import competition has triggered substantially larger increases in female employment than male employment (Panel C of Table 4). These results highlight that tariff reductions not only affected total female employment at the prefecture level, but more specifically also drove female employment within private formal industrial firms.

\subsection{Identification and robustness}

Our results can only be given a causal interpretation if prefecture-level import tariff reductions can be considered exogenous. The import tariff coefficients will be biased if the magnitude or timing of tariff reductions was endogeneous, or if confounding trends were correlated with the initial industry structure of prefectures. In the following, we discuss the relevance of these concerns and present a series of robustness checks.

Upon accessing the WTO, China followed through on its obligation to reduce tariffs substantially, without considerable exemptions, which alleviates concerns about the endogeneity of the magnitude of sectoral tariff cuts. The timing of sectoral tariff cuts could have still been endogenous though, with more influential industries experiencing later tariff reductions. However, as we analyse long-run effects of tariff reductions over 10 to 15 years, our estimates do not rely on short-run variation in tariff cuts. This is confirmed by the extremely high correlation between initial levels of protection and tariff reductions both at the industry and at the prefecture level from 1990 to 2005 (see Figure A.4 in the Appendix). A remaining issue arises as China committed to reduce its tariffs until 2010, whereas our sample ends in 2005. If factors that explain the delay in tariff reductions until the latest years were correlated with the sectoral labor market dynamics, this would bias our estimates. In practice, however, this concern also does not seem to have played a substantial role. The vast majority of tariff reductions have been completed before 2005 while average tariffs have reduced by only 1.3 percentage points between 2005 and 2010. Panel A of Table 5 controls for these two issues more formally, using an instrumental variable regression approach and employing the average level of initial 
import tariffs (in 1992) as instruments for average import tariff reductions at the prefecture level (following, e.g., Goldberg and Pavcnik, 2005 and Amiti and Cameron, 2012). Our results stay practically the same when using this two-stage least square (2SLS) specification.

Even if tariff reductions were fully pre-determined, the structure of initial tariff protection cannot be considered to be fully exogenous. Tariff protection has been substantially higher in specific industries (e.g., tobacco, furniture, or textiles), and the initial spatial location of these industries has been determined by a host of regional characteristics. These characteristics could have both contributed to a larger exposure to tariff reductions and may have driven the long-run trends in employment decline among both genders as well as the rising gender employment gap. Omitting these characteristics from the regressions will result in omitted variable bias. We address this concern first by controlling for a set of initial characteristics in all specifications, including the initial level of the dependent variables, the initial share of SOE employment, the initial employment shares in the agriculture and nontradable sectors, and initial nightlights to proxy for general economic development.

As a further test, Panels B and C of Table 5 check for the link between the pre-trends in employment and subsequent tariff reductions explicitly. Panel B presents the results from a falsification test by regressing the change in pre-sample labor market outcomes (the pretrend in employment from 1982 to 1990) on the tariff changes over our sample period, with the expectation that future tariff reductions should not be linked to changes in the gender employment gap in the past. We calculate the historical male and female employment rates based on the 1982 population census, which is also obtained from the IPUMS-International database (Minnesota Population Center, 2019), and regress employment changes between 1982 and 1990 on tariff changes between 1992 and 2005. Results in Panel B show no correlation between employment changes in the previous decade and import tariffs. To further verify that our results are not driven by the long-run trends, we augment equation (2) by adding the pre-sample trends in employment rates as further controls and report the results in panel C of Table 5. The estimated coefficients are not sensitive to the inclusion of the pre-sample trends in employment rates.

Table 6 re-estimates the main results from Table 2 by changing the underlying sample, decomposing the tariff variable, and controlling for further possible policy confounders. First, Panel A replicates our main results using the sub-sample of non-migrants only. The local labor market approach in our specification assumes no migration across regions. In reality, workers may move towards regions experiencing larger trade-induced increases in labor demand, leading to an under-estimation of the effects of trade liberalization on employment. Due to the presence of the household registration (hukou) system, inter-regional migration is highly costly in China (Meng, 2012). According to the population census, migrants from other prefectures (including those from other provinces) accounted for merely 2.5 percent of the working-age population in 1990, although their population shares increased to 8.2 percent in 2005 . When focusing on the non-migrant sample only, the point estimates slightly decrease in magnitude but the overall patterns remain the same.

In Panel B of Table 6, we decompose the import tariff reductions by their main sector into agricultural versus industrial tariffs, the sum of which yields our original import tariff 
measure. The results show that female employment as well as the gender employment gap are primarily driven by changing industrial tariffs and not by agricultural tariff changes and hence competition dynamics within the industrial sectors were contributing to changes in female employment.

Panel C of Table 6 introduces a list of further possible confounders that proxy for other dimensions of trade-related policies that were instituted during the same time period. Our measure for NTBs controls for regional exposure to reductions in non-tariff barriers (based on Brandt et al., 2017), which could have mitigated but also reinforced the effects of tariff reductions. On the export market access side, we measure aggregate export market access through a weighted regional export tariff measure, calculated with respect to all potential trading partners. Additionally, we control for changing access to the U.S. export market by measuring the difference between tariffs applied within the "normal trade relations" (NTR) framework that China qualified for and those applied towards non-market economies (from Facchini et al., 2019). Changing export subsidies and export licensing requirements measure a further dimension of export market access. Finally, we also control for the regional exposure to reducing limitations on FDI (based on Brandt et al., 2017) as foreign firms may also increase the demand for female labor (Juhn et al., 2014; Tang and Zhang, 2017).

The results show that only few of the above listed alternative policy channels are linked to employment changes, and none of them explain gender-specific differences in employment rates beyond the effects of import competition. The estimated coefficients of all controlled policy variables are positive both for males and females (columns 1 and 2), but are largely insignificant except for U.S. market access, measured by the change in the NTR gap for both genders, and FDI restrictions for females. Declines in trade policy uncertainties in exports towards the U.S. (measured by the NTR gap) are linked to lower employment rates for both genders. These dynamics can be explained by the inflows of migrants, which surpassed increases in the demand for workers within the local labor market (Facchini et al., 2019). Finally, the positive coefficient on FDI restrictions suggests that, surprisingly, liberalizing foreign investment led to reductions in female employment. One potential explanation could be that the technology effects of FDI disproportionately increased the demand for high-skilled workers, but squeezed out even more job opportunities for low-skilled females. ${ }^{9}$ More importantly for us, none of these policy changes affected males and females differently, as shown in column (3). Our main findings on the impact of tariff reductions remain unchanged, demonstrating that the gender-specific employment effects of trade liberalization were not driven by other contemporaneous trade policy changes, and hence are precisely identified.

In our prefecture-level regressions we focus on local averages and do not control for any individual characteristics that determine individual employment decisions. As a further robustness check, we rerun our baseline regressions using individual-level data from the 1990 and 2005 waves of the population census. Our dependent variable indicates individual employment. We control for a rich set of individual characteristics, including age, age squared, education level, hukou type, marital status, ethnicity, household head status, household size,

\footnotetext{
${ }^{9}$ These results are also in line with similar findings on the link between a strengthening of FDI regulations and increasing employment in Indonesian districts (Genthner and Kis-Katos, 2019).
} 
and an indicator for being a migrant. Additionally, we include prefecture and time fixed effects and a further set of prefecture-level initial conditions, shown in Table 2 as interaction terms with the 2005 year dummy. The results are reported in Table A.5 in the Appendix and are fully consistent with our main findings in Table 2. As before, import tariff reductions are not linked to male employment but increase the probability of employment for females. Coefficient sizes differ because individual-level regressions weight larger prefectures more heavily by default whereas regional-level estimates treat each region symmetrically. ${ }^{10}$

\section{Examining potential mechanisms}

Stronger import competition could induce a relative increase in female employment for a number of reasons. If sectoral employment is segregated by gender due to social or cultural norms, and these gender norms persist, structural change that leads to an expansion of historically female-intensive industries within the local labor market will mechanically reduce the gender gap in employment. Under persistent gender segregation in the labor markets, tariff reductions may disproportionately affect female employment if initially female-intensive sectors expanded following trade liberalization. Alternatively, increased competition may also contribute to a desegregation of sectors, either via a labor supply channel, by shifting cultural norms and reducing the preference for segregated employment, or via labor demand, by reducing discrimination against females and improving female labor market access. Aside from simply causing desegregation, increasing competition may also reduce discrimination directly, by increasing the willingness of all firms to employ females. A further possible reason for a reduction in the gender employment gap could lie in technological upgrading. Firms may respond to import competition by investing more in innovation or upgrading their technologies (Bloom et al., 2016). This may benefit females by reducing males' comparative advantage in physical strength and improving job opportunities for females in occupations that traditionally required intensive physical strength (Juhn et al., 2014). Finally, supply-side responses at the household level can also contribute to a reduction in the gender employment gap. As labor supply among adult females is generally more responsive to income shocks, if import liberalization results in wage losses, it will lead to relatively more females staying in the labor market.

We investigate these channels in two ways. First, we assess how changes in the factors listed above were linked to exposure to import tariff reductions across prefectures, which provides suggestive evidence on whether they could have contributed to changes in gender employment gaps. As a second test, we also add the channel variables jointly to our baseline regressions for a ceteris paribus investigation of within-prefecture dynamics. We provide these latter results only for a comparison, and are fully aware of the limitations of their interpretability. Since all channel variables responded endogenously to tariff reforms as well, their inclusion when controlling for import tariffs does not allow for a precise attribution of the most relevant mechanisms at play.

\footnotetext{
${ }^{10}$ Using prefectures' population as a share of the national population in 1990 as a weight in the regional-level estimation yields similar results to those in Table A.5.
} 


\subsection{Measurement of channel variables}

We measure the mechanical expansion of female-intensive industries as a shift-share variable (following Kis-Katos et al., 2018), where the share component consists of the initial female intensity (share of females among all workers) of each two-digit sector $s$ at the national level, $F I_{s 0}$, measured in $1990 .{ }^{11}$ The shift component, $E_{s p t} / E_{p t}$, measures the employment expansion of each sector $s$ within prefecture $p$ across the two time periods:

$$
F I_{p t}=100 \cdot \sum_{s=1}^{S}\left(\frac{E_{s p t}}{E_{p t}} \times F I_{s 0}\right)
$$

This measure abstracts from total changes in employment within each prefecture and isolates shifts in the sectoral distribution of employment. The change in this variable will be larger in a given prefecture if sectors that used to be historically female-intensive (at the national level) expanded locally over time.

As an additional measure, we assess the change in sectoral gender segregation by measuring changes in a dissimilarity index that captures prefecture-level sectoral segregation of the workforce by gender (e.g., Kis-Katos et al., 2018; Borrowman and Klasen, 2020):

$$
S I_{p t}=100 \cdot \frac{1}{2} \sum_{s=1}^{S}\left|\frac{M_{s p t}}{M_{p t}}-\frac{F_{s p t}}{F_{p t}}\right|
$$

where $M_{s p t} / M_{p t}$ and $F_{s p t} / F_{p t}$ denote the share of male and female workers in two-digit sector $s$ in prefecture $p$, respectively. The value of this index is scaled between 0 and 100, with a larger value indicating higher sectoral segregation by gender. If trade liberalization reduced sectoral gender segregation, this would indicate that females gained improved opportunities in conventionally male-dominated sectors, or that males became more likely to enter originally female-intensive sectors.

We proxy gender discrimination in the local labor markets more directly by building on Hellerstein et al. (2002) and Hellerstein and Neumark (2006), approximating the local prevalence of more discriminating sectors, identified via the amount of excess profits among firms employing a larger share of females within each sector. The underlying assumption is that within a sector that contains both discriminating and non-discriminating employers, nondiscriminating firms should be able to earn higher profits according to Becker's (1957) theory of discrimination. Hence, a larger profit differential between otherwise comparable firms that employ more versus fewer females can be taken as an indication of a higher prevalence of gender discrimination within that sector. To construct this measure, we rely on firm census data from 1995 and 2004 and regress firm operating profits on the female share separately for each two-digit sector $s$ and year $t$, using the following specification:

$$
\Pi_{f s t}=\beta^{s t} F S h_{f s t}+\gamma^{s t} X_{f s t}+\varepsilon_{f s t}
$$

\footnotetext{
${ }^{11}$ Due to the fact that the 2005 mini census only reports two-digit sector codes, we can only calculate employment shares of each two-digit sector within prefectures for 2005. We therefore aggregate the three-digit codes in 1990 to two-digit codes.
} 
where $\Pi_{f s t}$ denotes the inverse hyperbolic sine of profits obtained by firm $f$ operating in twodigit sector $s$ and year $t$. Our main variable of interest is $F S h_{f s t}$, which measures the share of female workers among each firm's employees. The vector of controls $X_{f s t}$ includes each firm's output share within the product market to measure its market power, categories of firm age, its share of skilled employees, an indicator for exporter status and an indicator of private ownership. We collect the industry- and year-specific coefficients $\widehat{\beta}^{\text {st }}$, which capture timevariant sectoral estimates of the relative strength of labor market gender discrimination against females. A positive value of $\widehat{\beta}^{\text {st }}$ indicates the existence of discrimination against women. We transform these sectoral discrimination coefficients, $\widehat{\beta}^{\text {st }}$, into a prefecture-wide discrimination index, $D I_{p t}$, that computes the local prevalence of discriminating sectors by using industrial employment shares of each sector $s$ in year $t$ within each prefecture $p$ as weights:

$$
D I_{p t}=\sum_{s=1}^{S} \frac{E_{s p t}}{E_{p t}} \widehat{\beta}^{s t}
$$

By relying on time-variant employment weights, $E_{s p t} / E_{p t}$, our prefecture-level discrimination measure will decline if either employment shifts towards less discriminating sectors within each prefecture or if within-sector discrimination declines at the national level (or both).

We capture upgrades in technology by focusing on the spread of computerization within each prefecture. ${ }^{12}$ For this, we first compute the share of computers within the total value of machinery for medium and large industrial firms within two-digit industries, provided by China Statistical Yearbook on Science and Technology (1991, 1996, 2005, and 2006). In a second step, we use the population censuses of 1990 and 2005, as well as the industrial and firm censuses of 1995 and 2004, to measure the relative importance of each two-digit industry within each prefecture and compute a prefecture-year specific index of computer intensity, $C I_{p t}$ :

$$
C I_{p t}=100 \cdot \sum_{s=1}^{S} \frac{E_{s p t}}{E_{p t}} C I_{s t}
$$

which reweighs the sectoral computer intensity, $C I_{s t}$, by time-variant within-prefecture employment shares, $E_{s p t} / E_{p t}$, resulting in a direct measure of computerisation within each prefecture.

We do not have good aggregate information that would allow us to precisely measure income changes within these 311 prefectures over time. Although GDP measures at the prefecture-level are reported in National Statistical Yearbooks, a substantial share of prefectures is missing this information, especially in earlier time periods. We resort instead to a rough proxy of local economic development that has been increasingly used as a proxy for economic activity and welfare in the literature (e.g. Henderson et al., 2012; Donaldson and Storeygard, 2016), by measuring nightlight intensity within each prefecture's borders in 1990 and 2005 as a generic proxy of economic activity and income.

\footnotetext{
${ }^{12}$ An alternative measure, focusing on technician-intensive occupations, yields qualitatively very similar results.
} 


\subsection{Results}

Table 7 shows the results from regressing each of the above channel variables on prefecturelevel import tariff exposure and the same set of initial conditions that we have used in our previous analyses. Panel A of Table 7 focuses on the expansion of originally female dependent sectors. Average trends (captured by the mean dependent variable) show that the share of originally female-intensive industries declined within the local labor markets and within the formal industrial sector, irrespective of ownership structures. The regression results reveal a negative link between local import tariff exposure and the size of female-intensive sectors within each location as well as the size of initially female-intensive employment within local private industrial firms. Import competition was thus associated with an expansion of the female-intensive production, both in the local economy and in the local private industrial sector. This somewhat counteracted the general reduction in female employment, thereby reducing the rise in the female employment gap as documented in Tables 2 to 4 . This importcompetition induced expansion of female-intensive sectors may have contributed to an increase in female employment, but only if sectoral gender segregation remained persistently present throughout time.

The possibility of such an alternative dynamic is investigated in panel B of Table 7 . The general trends show a marked increase in sectoral gender segregation within the Chinese prefectures of about 7.4 percentage points, but this dynamic was not driven by formal industrial firms, who instead experienced a much smaller rise in gender segregation, and SOEs even experienced a reduction in gender segregation. These descriptive changes, however, show evidence of persistent gender segregation in the local market, thereby supporting the first channel of import-competition induced expansion of female-intensive sectors. The regression results show that import tariff declines and the resulting international market competition were linked to reductions in the sectoral segregation of overall employment, and imply that females may have gained improved job opportunities in traditionally male-dominant sectors. This is in stark contrast to the within-industry results, as sectoral segregation tended to increase in all formal industrial firms and among private companies with more import competition, although these results are statistically insignificant. Together with the previous results, this shows that within the private formal industrial sector, there was not only an expansion of female-intensive industries but also an increase in gender segregation of employment, again potentially favoring female employment.

These processes were accompanied by falling gender discrimination due to import competition. As discrimination is approximated using firm-level profit data, we cannot compute this measure for the entire local economy, but the trends reported in Panel $\mathrm{C}$ show substantial decreases in average discrimination over time among all formal firms. With an initial average value of 9.0 in 1990, a reduction of 5.8 among all formal industrial firms indicates a decline by more than two thirds in average discrimination against women. A similar pattern is observed for private firms, whereas SOEs experienced the largest reductions in discrimination. The regression results show that increases in import competition were significantly contributing to reductions in discrimination among all firms and among private formal industrial enterprises. This result 
is in line with the expectation that discrimination by employers should respond strongly to market competition (Becker, 1957).

In order to investigate the relevance of the technology channel, Panel D focuses on the local expansion of computerization over time. Surprisingly, the trends show only minor aggregate increases in technology (computer) intensity over the examined time period. However, there are practically no changes among all formal enterprises, which masks substantial structural shifts by ownership category: private formal enterprises increased their computer intensity more substantially, which has been counteracted by comparable declines among SOEs. This also shows that privatization and new firm formation was more prevalent in the more technology intensive sectors. The regression results show that import tariffs induced competitive pressures which contributed particularly to computerization of private formal enterprises, but were negatively linked to the computerization of local SOEs. The results do not preclude the possibility that technological change has also contributed to rising female employment among private formal enterprises, although the same effects are less likely to have played a role in the local economy as a whole.

Finally, relying on nightlight data, panel E shows an average increase in economic activity over time. As compared to the initial average value of 2.4 (see Table A.1), an increase in nightlight intensity of 2.0 indicates a growth rate of 83.3 percent for local economic activities, on average. The regression results demonstrate that places exposed to larger import tariff reductions were growing more quickly than others, and hence the average income effects of import competition in the long run may have been positive. We would expect female employment to decline in response to average increases in household incomes, as females of child-bearing age became more likely to abstain from the labor market in the 2000s than in the previous decade. This dynamic, however, would have resulted in a widening of the gender employment gap and hence is unlikely to be the driving force behind our gender gap results. A remaining caveat of this analysis is that at this aggregated level nightlights may be better able to capture labor demand effects of increasing production and urbanization instead of potential supply-side adjustments due to increasing household incomes.

Table A.6 in the Appendix presents an alternative set of results controlling jointly for each of the above channels through various regressions of changes in gender-specific employment in the local economy and in private formal industrial firms on import tariff changes. We focus on these two types of employment as they have experienced the most consistent reductions in the gender employment gap. We only view this evidence as suggestive, since all of the channel variables responded to tariff reductions themselves (see Table 7), so our ability to provide a true ceteris paribus comparison is rather limited in this setting. First and foremost, the negative link between import tariffs and gender employment gap persists both within the local economy and private formal industrial firms also when controlling for these channel variables. This could point towards the importance of further explanatory factors, but also to possible limitations in how we operationalize the selected channels. Additionally, several of the potential channel variables are also correlated with gendered employment outcomes, even after tariff effects are controlled for. The gender employment gap shrank in prefectures that were experiencing the expansion of originally more female-intensive sectors (beyond what was predicted by 
tariff declines), as well as a decreasing gender segregation of employment at the level of local labor markets (but not in private firms). None of the further factors are significantly different across the genders: neither declines in gender discrimination, nor changing computerization, nor general growth are linked to the gender employment gap once tariffs are controlled for. Computerization coincided with a substantial expansion of private industrial employment of both males and females, providing no additional evidence for new technologies having particularly favoured female employment in China. Finally, increases in income as proxied by nightlights are also linked to increases in both male and female employment, without any notable gender difference.

\section{Conclusion}

Since the mid-1990s, China has undergone major trade reforms, liberalizing its trade regime and opening its markets to global competition. These reforms were accompanied by substantial structural change and a declining trend of employment rates both among males and females. As females were leaving the workforce in larger numbers, potentially also driven by adjustments of labor supply, China experienced a widening gender gap in employment over time. This paper aims to link these two long-run dynamics and investigates to what extent labor demand adjustments due to trade liberalization contributed to or counteracted this widening gender employment gap. To this end, we employ a local labor market approach and relate changes in local employment outcomes to regional exposure of tariff rate reductions. We focus on shifts in total local employment (based on population census waves), but complement our results with shifts in formal industrial employment (based on industrial and economic census waves).

In line with the emerging literature that finds gender-specific effects of trade liberalization in developing countries (e.g., Juhn et al., 2014; Gaddis and Pieters, 2017; Kis-Katos et al., 2018; Ben Yahmed and Bombarda, 2020), we find robust evidence that import tariff reductions fostered female employment. Prefectures that were more strongly exposed to import tariff reductions experienced reductions (smaller increases) in their male-to-female employment gap. Census data on formal industrial firms reveals that increasing import competition was especially linked to expanding private sector employment of females, with a shrinking gender employment gap in private enterprises. These results are in line with several possible underlying explanations, all linked to changes in labor demand and structural change. Part of these adjustments have been mechanically driven by sectoral expansion in segregated labor markets, as China's import tariff reductions were linked to expansions of originally female intensive industries. Proxies for sectoral gender discrimination also reduced with more import competition, very much in line with theoretical expectations, whereas private enterprises responded to competitive pressures with technological upgrading. Finally, import competition was linked to relative increases in local economic activity (measured by nightlights). Our analysis cannot identify the one main channel behind these results, but shows that all of these dynamics could have limited the growth of a gender employment gap.

The findings in this paper shed some light on the unintended gender-specific employment effects of trade liberalization in China and potentially in other developing countries. Existing literature 
finds that trade liberalization tended to widen inequality in developing countries (Goldberg and Pavcnik, 2007). The import-competition induced reduction in the gender employment gap as documented in this paper, however, implies that opening to the world economy may still have had welfare-improving effects by contributing to more equal employment opportunities by gender. 


\section{References}

Amiti, Mary and Lisa Cameron, "Trade Liberalization and the Wage Skill Premium: Evidence from Indonesia," Journal of International Economics, 2012, 87 (2), 277-287.

Bartik, Timothy J., Who Benefits from State and Local Economic Development Policies?, Kalamazoo, Michigan: W.E. Upjohn Institute for Employment Research, 1991.

Becker, Gary S., The Economics of Discrimination, The University of Chicago Press, 1957.

Ben Yahmed, Sarra and Pamela Bombarda, "Gender, Informal Employment and Trade Liberalization in Mexico," The World Bank Economic Review, June 2020, 34 (2), 259-283.

Black, Sandra E. and Elizabeth Brainerd, "Importing Equality? The Impact of Globalization on Gender Discrimination," ILR Review, July 2004, 57 (4), 540-559.

Bloom, Nicholas, Mirko Draca, and John Van Reenen, "Trade Induced Technical Change? The Impact of Chinese Imports on Innovation, IT and Productivity," The Review of Economic Studies, 2016, 83 (1), 87-117.

Borrowman, Mary and Stephan Klasen, "Drivers of Gendered Sectoral and Occupational Segregation in Developing Countries," Feminist Economics, 2020, 2 (26), 62-94.

Brandt, Loren, Johannes Van Biesebroeck, Luhang Wang, and Yifan Zhang, “WTO Accession and Performance of Chinese Manufacturing Firms," American Economic Review, September 2017, 107 (9), 2784-2820.

Chen, Bo, Miaojie Yu, and Zhihao Yu, "Measured Skill Premia and Input Trade Liberalization: Evidence from Chinese Firms," Journal of International Economics, 2017, 109 (C), 31-42.

Chen, Xi and Suqin Ge, "Social Norms and Female Labor Force Participation in Urban China," Journal of Comparative Economics, 2018, 46 (4), 966-987.

Chen, Zhihong, Ying Ge, Huiwen Lai, and Chi Wan, "Globalization and Gender Wage Inequality in China," World Development, 2013, 44 (C), 256-266.

Chi, Wei and Bo Li, "Trends in China's Gender Employment and Pay Gap: Estimating Gender Pay Gaps with Employment Selection," Journal of Comparative Economics, 2014, 42 (3), 708-725.

Dai, Mi, Wei Huang, and Yifan Zhang, "How Do Households Adjust to Trade Liberalization? Evidence from China's WTO Accession," IZA Discussion Papers 11428, Institute of Labor Economics (IZA) 2018.

de Bruin, Anne and Na Liu, "The Urbanization-Household Gender Inequality Nexus: Evidence from Time Allocation in China," China Economic Review, April 2020, 60, 101301.

Dix-Carneiro, Rafael and Brian K. Kovak, "Trade Liberalization and Regional Dynamics," American Economic Review, October 2017, 107 (10), 2908-2946.

Donaldson, Dave and Adam Storeygard, "The View from Above: Applications of Satellite Data in Economics," Journal of Economic Perspectives, Fall 2016, 30 (4), 171-198. 
Facchini, Giovanni, Maggie Y. Liu, Anna Maria Mayda, and Minghai Zhou, "China's "Great Migration": The Impact of the Reduction in Trade Policy Uncertainty," Journal of International Economics, 2019, 120, 126-144.

Gaddis, Isis and Janneke Pieters, "The Gendered Labor Market Impacts of Trade Liberalization: Evidence from Brazil," Journal of Human Resources, 2017, 52 (2), 457-490.

Genthner, Robert and Krisztina Kis-Katos, "Foreign Investment Regulation and Firm Productivity: Granular Evidence from Indonesia," Center for European, Governance and Economic Development Research Discussion Papers 345, University of Göttingen, Department of Economics 2019.

Goldberg, Pinelopi Koujianou, Amit Kumar Khandelwal, Nina Pavcnik, and Petia Topalova, "Imported Intermediate Inputs and Domestic Product Growth: Evidence from India," The Quarterly Journal of Economics, 2010, 125 (4), 1727-1767.

Goldberg, Pinelopi Koujianou and Nina Pavcnik, "Trade, Wages, and the Political Economy of Trade Protection: Evidence from the Colombian Trade Reforms," Journal of International Economics, May 2005, 66 (1), 75-105.

Goldberg, Pinelopi Koujianou and Nina Pavcnik, "Distributional Effects of Globalization in Developing Countries," Journal of Economic Literature, March 2007, 45 (1), 39-82.

Han, Jun, Runjuan Liu, and Junsen Zhang, “Globalization and Wage Inequality: Evidence from Urban China," Journal of International Economics, 2012, 87 (2), 288-297.

Hare, Denise, "What Accounts for the Decline in Labor Force Participation among Married Women in Urban China, 1991-2011," China Economic Review, 2016, 38 (C), 251-266.

Hellerstein, Judith K. and David Neumark, "Using Matched Employer-Employee Data to Study Labor Market Discrimination," in "Handbook on the Economics of Discrimination," Edward Elgar Publishing, 2006, chapter 2.

Hellerstein, Judith K., David Neumark, and Kenneth R. Troske, "Market Forces and Sex Discrimination," Journal of Human Resources, 2002, 37 (2), 353-380.

Henderson, J. Vernon, Adam Storeygard, and David N. Weil, "Measuring Economic Growth from Outer Space," American Economic Review, April 2012, 102 (2), 994-1028.

Hirata, Guilherme and Rodrigo R. Soares, "Competition and the Racial Wage Gap: Testing Becker's Model of Employer Discrimination," IZA Discussion Papers 9764, Institute of Labor Economics (IZA) February 2016.

Juhn, Chinhui, Gergely Ujhelyi, and Carolina Villegas-Sanchez, "Men, Women, and Machines: How Trade Impacts Gender Inequality," Journal of Development Economics, 2014, 106 (C), 179-193.

Kis-Katos, Krisztina and Robert Sparrow, "Poverty, Labor Markets and Trade Liberalization in Indonesia," Journal of Development Economics, 2015, 117, 94-106. 
Kis-Katos, Krisztina, Janneke Pieters, and Robert Sparrow, "Globalization and Social Change: Gender-Specific Effects of Trade Liberalization in Indonesia," IMF Economic Review, December 2018, 66 (4), 763-793.

Klasen, Stephan, "What Explains Uneven Female Labor Force Participation Levels and Trends in Developing Countries?," World Bank Research Observer, 2019, 34 (2), 161-197.

Klasen, Stephan and Janneke Pieters, "What Explains the Stagnation of Female Labor Force Participation in Urban India?," World Bank Economic Review, 2015, 29 (3), 449-478.

Kovak, Brian K., "Regional Effects of Trade Reform: What Is the Correct Measure of Liberalization?," American Economic Review, August 2013, 103 (5), 1960-76.

Li, Bingjing, "Export Expansion, Skill Acquisition and Industry Specialization: Evidence from China," Journal of International Economics, 2018, 114 (C), 346-361.

Li, Jie, Yi Lu, Hong Song, and Huihua Xie, "Long-term Impact of Trade Liberalization on Human Capital Formation," Journal of Comparative Economics, 2019, 47 (4), 946-961.

Li, Shi and Jin Song, "Changes in the Gender-Wage Gap in Urban China, 1995-2007," in Li Shi, Sato Hiroshi, and Sicular Terry, eds., Rising Inequality in China: Challenges to a Harmonious Society, Cambridge University Press, 2013, pp. 384-413.

Liang, Zhe, Simon Appleton, and Lina Song, "Informal Employment in China: Trends, Patterns and Determinants of Entry," IZA Discussion Papers 10139, Institute of Labor Economics (IZA) August 2016.

Liao, Chuan and Ding Fei, "Poverty Reduction through Photovoltaic-based Development Intervention in China: Potentials and Constraints," World Development, 2019, 122 (C), 1-10.

Lu, Yi and Linhui Yu, "Trade Liberalization and Markup Dispersion: Evidence from China's WTO Accession," American Economic Journal: Applied Economics, October 2015, 7 (4), 221-253.

Ma, Hong, Xue Qiao, and Yuan Xu, “Job Creation and Job Destruction in China during 19982007," Journal of Comparative Economics, 2015, 43 (4), 1085-1100.

Maurer-Fazio, Margaret, Rachel Connelly, Lan Chen, and Lixin Tang, "Childcare, Eldercare, and Labor Force Participation of Married Women in Urban China, 1982-2000," Journal of Human Resources, 2011, 46 (2), 261-294.

Meng, Xin, "Labor Market Outcomes and Reforms in China," Journal of Economic Perspectives, Fall 2012, 26 (4), 75-102.

Minnesota Population Center, "Integrated Public Use Microdata Series, International: Version 7.2 [dataset]. Minneapolis, MN: IPUMS," https://doi.org/10.18128/D020.V7.2 2019. Accessed: 2019-01-01.

National Bureau of Statistics, China City Statistical Yearbook, China Statistics Press, 1991. 
National Bureau of Statistics, China Statistical Yearbook on Science and Technology, China Statistics Press, 1991.

National Bureau of Statistics, China Statistical Yearbook on Science and Technology, China Statistics Press, 1996.

National Bureau of Statistics, China Statistical Yearbook on Science and Technology, China Statistics Press, 2005.

National Bureau of Statistics, China Statistical Yearbook on Science and Technology, China Statistics Press, 2006.

Ou, Dongshu and Zhong Zhao, "Higher Education Expansion and Labor Market Outcomes for Young College Graduates," IZA Discussion Papers 9643, Institute of Labor Economics (IZA) January 2016.

Pierce, Justin R. and Peter K. Schott, "The Surprisingly Swift Decline of US Manufacturing Employment," American Economic Review, July 2016, 106 (7), 1632-1662.

Rodriguez-Lopez, Antonio and Miaojie Yu, "All-Around Trade Liberalization and Firm-Level Employment: Theory and Evidence from China," CESifo Working Paper Series 6710, CESifo Group Munich October 2017.

Sauré, Philip and Hosny Zoabi, "International Trade, the Gender Wage Gap and Female Labor Force Participation," Journal of Development Economics, November 2014, 111 (0), 17-33.

Tang, Heiwai and Yifan Zhang, “Do Multinationals Transfer Culture? Evidence on Female Employment in China," CESifo Working Paper Series 6295, CESifo Group Munich 2017.

Topalova, Petia, "Factor Immobility and Regional Impacts of Trade Liberalization: Evidence on Poverty from India," American Economic Journal: Applied Economics, October 2010, 2 (4), 1-41.

Xu, Mingzhi, "Globalization, the Skill Premium, and Income Distribution: The Role of Selection into Entrepreneurship," Technical Report, Peking University and NBER 2019.

Yu, Miaojie, "Processing Trade, Tariff Reductions and Firm Productivity: Evidence from Chinese Firms," Economic Journal, June 2015, 125 (585), 943-988. 


\section{Figures}

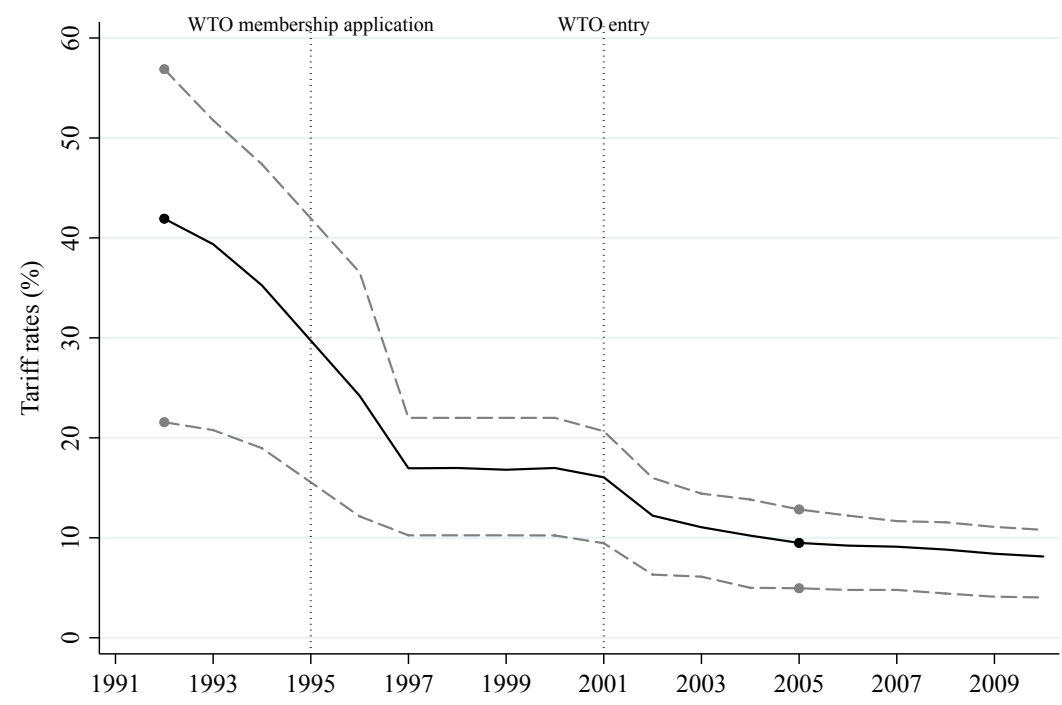

Figure 1: Import tariff rates in China: 1992-2010

Notes: Product-level tariffs at the HS 6-digit level are mapped into 162 three-digit Chinese Industry Classification (CIC) industries. The solid line shows the mean tariffs across industries and dashed lines show the 25th and 75th percentiles of tariffs. The dots indicate the mean, 25th, and 75th percentiles of tariffs of the two years (1992 and 2005) used to calculate long-run tariff changes in this paper. Data of product-level tariffs are from WITS.

\section{Tables}

Table 1: Participation rate of working age population by gender: 1990 and 2005 (\%)

\begin{tabular}{|c|c|c|c|c|c|c|}
\hline \multirow[b]{2}{*}{ Working status } & \multicolumn{3}{|c|}{1990} & \multicolumn{3}{|c|}{2005} \\
\hline & Male & Female & M-F Diff. & Male & Female & M-F Diff. \\
\hline Employed & 90.35 & 84.83 & 5.53 & 81.86 & 71.55 & 10.31 \\
\hline Age cohort 15-25 & 79.14 & 80.04 & -0.90 & 52.08 & 50.87 & 1.21 \\
\hline Age cohort 26-35 & 98.43 & 90.72 & 7.72 & 94.27 & 80.16 & 14.11 \\
\hline Age cohort 36-50 & 98.35 & 86.03 & 12.32 & 93.31 & 79.80 & 13.50 \\
\hline Unemployed & 0.90 & 0.92 & -0.02 & 2.09 & 1.69 & 0.40 \\
\hline Non-participation & 8.08 & 13.90 & -5.82 & 15.46 & 26.24 & -10.78 \\
\hline
\end{tabular}

Notes: This table shows the employment rate, unemployment rate, and non-labor force participation rate for working age population (15-50, and by age cohort), by gender, in 1990 and 2005, based on the population census waves. All rates are calculated as the share of male and female employed, unemployed and non-participants over male and female population, respectively. Employment rates by age cohort are calculated as the share of male and female employed, for each age cohort, over the male and female population of the corresponding age cohort. 
Table 2: Import tariffs and prefecture city-level employment rates, 1990-2005

\begin{tabular}{|c|c|c|c|c|}
\hline & \multicolumn{3}{|c|}{ Dependent: $\Delta$ Employment rate } & \multirow[b]{2}{*}{$\begin{array}{l}\text { M-F Diff. } \\
(2)-(3)\end{array}$} \\
\hline & $\begin{array}{l}\text { All } \\
(1)\end{array}$ & $\begin{array}{l}\text { Male } \\
(2)\end{array}$ & $\begin{array}{c}\text { Female } \\
\text { (3) }\end{array}$ & \\
\hline$\Delta$ Import tariffs & $\begin{array}{l}-0.22^{* *} \\
(2.32)\end{array}$ & $\begin{array}{c}-0.13 \\
(1.56)\end{array}$ & $\begin{array}{l}-0.33^{* *} \\
(2.48)\end{array}$ & $\begin{array}{l}0.20^{* *} \\
(1.98)\end{array}$ \\
\hline Mean dependent (pp.) & -10.24 & -7.77 & -12.40 & 4.63 \\
\hline
\end{tabular}

Notes: Regression results are reported in columns (1) to (3), using robust standard errors. Columns (2) and (3) are jointly estimated. The last column reports the difference in coefficients between regressions for males and females (gender employment gap). Dependent variables measure the change in the share of employment within working age population (in total and by gender), derived from the population censuses of 1990 and 2005. Initial conditions include the 1990 level of the dependent variable (total, male or female employment shares), the share of SOE employment, employment shares of the agriculture and tertiary sectors, as well as nightlights, all measured in $1990 . N=311 .{ }^{*} p<0.1,{ }^{* *} p<0.05,{ }^{* * *} p<0.01$. Absolute $t$ values in parentheses. 
Table 3: Import tariffs and prefecture city-level employment by age and skill group, 1990-2005

\begin{tabular}{|c|c|c|c|}
\hline & \multicolumn{2}{|c|}{ Dependent: $\Delta$ Employment rate } & \multirow[b]{2}{*}{$\begin{array}{l}\text { M-F Diff. } \\
(1)-(2)\end{array}$} \\
\hline & $\begin{array}{c}\text { Male } \\
(1)\end{array}$ & $\begin{array}{c}\text { Female } \\
\text { (2) }\end{array}$ & \\
\hline \multicolumn{4}{|l|}{ Panel A: Aged 15-25 } \\
\hline$\Delta$ Import tariffs & $\begin{array}{l}-0.02 \\
(0.10)\end{array}$ & $\begin{array}{c}0.11 \\
(0.54)\end{array}$ & $\begin{array}{c}-0.13 \\
(1.27)\end{array}$ \\
\hline Mean dependent (pp.) & -27.06 & -29.20 & 2.14 \\
\hline \multicolumn{4}{|l|}{ Panel B: Aged 26-35 } \\
\hline$\Delta$ Import tariffs & $\begin{array}{l}-0.15^{* *} \\
(2.15)\end{array}$ & $\begin{array}{l}-0.56^{* * *} \\
(3.74)\end{array}$ & $\begin{array}{l}0.40^{* * *} \\
(3.22)\end{array}$ \\
\hline Mean dependent (pp.) & -4.41 & -10.81 & 6.40 \\
\hline \multicolumn{4}{|l|}{ Panel C: Aged 36-50 } \\
\hline$\Delta$ Import tariffs & $\begin{array}{l}-0.27^{* * *} \\
(3.21)\end{array}$ & $\begin{array}{l}-0.52^{* * *} \\
(3.54)\end{array}$ & $\begin{array}{l}0.25^{* *} \\
(1.97)\end{array}$ \\
\hline Mean dependent (pp.) & -4.86 & -4.77 & -0.09 \\
\hline \multicolumn{4}{|c|}{ Panel D: Low-skilled workers } \\
\hline$\Delta$ Import tariffs & $\begin{array}{l}-0.15 \\
(1.53)\end{array}$ & $\begin{array}{l}-0.37^{* *} \\
(2.29)\end{array}$ & $\begin{array}{c}0.22^{*} \\
(1.77)\end{array}$ \\
\hline Mean dependent (pp.) & -8.75 & -12.56 & 3.81 \\
\hline \multicolumn{4}{|c|}{ Panel E: High-skilled workers } \\
\hline$\Delta$ Import tariffs & $\begin{array}{l}-0.04 \\
(0.43)\end{array}$ & $\begin{array}{l}-0.31^{* *} \\
(2.18)\end{array}$ & $\begin{array}{l}0.27^{* *} \\
(2.13)\end{array}$ \\
\hline Mean dependent (pp.) & -7.50 & -15.55 & 8.05 \\
\hline
\end{tabular}

Notes: Regression results in columns (1) and (2) are jointly estimated using robust standard errors. The last column reports the difference in coefficients between regressions for males and females (the gender employment gap). Dependent variables measure the change in the share of employment within the selected age and skill groups (by gender), derived from the population censuses of 1990 and 2005. We consider workers as high-skilled if they have completed at least high-school (upper secondary education). All regressions control for the 1990 level of the dependent variable, initial SOE employment shares, initial employment shares of the agriculture and tertiary sectors, and initial nightlights. $N=311 .{ }^{*} p<0.1,{ }^{* *} p<0.05,{ }^{* * *} p<0.01$. Absolute $t$ values in parentheses. 
Table 4: Employment shares in state-owned and private formal industrial firms, 1995-2004

\begin{tabular}{lccc}
\hline & \multicolumn{2}{c}{ Dependent: $\Delta$ Employment rate } & Female \\
\cline { 2 - 4 } & $\begin{array}{c}\text { Male } \\
\text { Panel A: In all formal industrial firms }\end{array}$ & $\begin{array}{c}\text { M-F Diff. } \\
(1)-(2)\end{array}$ \\
\hline $\begin{array}{l}\text { Import tariffs } \\
\text { Mean dependent (pp.) }\end{array}$ & -0.21 & $-0.36^{* *}$ & $(1.17)$ \\
Panel B: In SOEs & $-1.14)$ & $(2.53)$ & 0.93 \\
\hline Import tariffs & & -2.54 & 0.01 \\
Mean dependent (pp.) & 0.09 & & $(0.24)$ \\
Panel C: In Non-SOEs & $(1.13)$ & $0.08^{* *}$ & -2.41 \\
\hline Import tariffs & -10.26 & $(2.10)$ & -7.85 \\
Mean dependent (pp.) & & & $0.25^{* *}$ \\
\hline
\end{tabular}

Notes: Regression results in columns (1) and (2) are jointly estimated, using robust standard errors. The last column reports the difference in coefficients between regressions for males and females (the gender employment gap). Dependent variables measure the change in the share of employment in each type of industrial firms from 1995 to 2004, normalized by the working age population (by gender). They are derived from the industrial economic census of 1995 and the economic census of 2004. SOEs include both state-owned enterprises and collective-owned enterprises. Formal private firms include domestic private firms and foreign-invested firms. All regressions control for the 1995 level of the dependent variable, initial SOE employment shares, initial employment shares of the agriculture and tertiary sectors, and initial nightlights. $N=311$. ${ }^{*} p<0.1{ }^{* *} p<0.05,{ }^{* * *} p<0.01$. Absolute $t$ values in parentheses. 
Table 5: Robustness checks: IV regressions and pretrends

Dependent: $\Delta$ Employment rate

Male $\quad$ Female M-F Diff.

(1) (2) (1) $-(2)$

Panel A: $\Delta$ Employment rate 1990-2005, 2SLS

$\Delta$ Import tariff instrumented by import tariff in 1992

\begin{tabular}{lccc}
\hline$\Delta$ Import tariffs & -0.12 & $-0.34^{* *}$ & $0.21^{* *}$ \\
& $(1.44)$ & $(2.57)$ & $(2.08)$ \\
Mean dependent (pp.) & -7.77 & -12.40 & 4.63
\end{tabular}

Panel B: Pre-trends: $\Delta$ Employment rate 1982-1990, OLS

\begin{tabular}{|c|c|c|c|}
\hline$\Delta$ Import tariffs & $\begin{array}{c}0.02 \\
(0.24)\end{array}$ & $\begin{array}{l}-0.10 \\
(0.72)\end{array}$ & $\begin{array}{c}0.13 \\
(0.87)\end{array}$ \\
\hline Mean dependent (pp.) & -1.01 & 1.09 & -2.10 \\
\hline \multicolumn{4}{|c|}{ Panel C: $\Delta$ Employment rate 1990-2005, OLS } \\
\hline$\Delta$ Import tariffs & $\begin{array}{l}-0.04 \\
(0.46)\end{array}$ & $\begin{array}{l}-0.32^{* *} \\
(2.37)\end{array}$ & $\begin{array}{l}0.27^{* * * *} \\
(2.66)\end{array}$ \\
\hline Controlling for pre-trends & Yes & Yes & \\
\hline Mean dependent (pp.) & -7.53 & -12.03 & 4.50 \\
\hline
\end{tabular}

Notes: Regression results in columns (1) and (2) are jointly estimated, using robust standard errors. The last column reports the difference in coefficients between regressions for males and females (the gender employment gap). Dependent variables measure the change in the share of employment within the working-age population (by gender), derived from the population censuses of 1982, 1990, and 2005. They measure the pre-trends (between 1982-1990) in Panel B, and the contemporaneous trend (between 1990-2005) in Panels A and C. Tariff changes are measured from 1992 to 2005. In Panel A, they are instrumented by initial tariff levels in 1992 (with first-stage a F-statistics of the excluded instrument being 1976.2). All regressions control for the initial level of the dependent variable and initial employment shares of the agriculture and tertiary sectors, (measured in 1990 in panels A and C and in 1982 in panel B). Panels A and C also control for initial SOE employment shares and nightlights in 1990. Panel C additionally controls for the pre-trend in the dependent variable (from 1982 to 1990). In Panel A, N = 311; in Panels B and C, $N=277$. The reduction of sample size in Panels B and C is due to the fact that some prefectures in 1982 cannot be matched to the 1990 codes as a result of changes in administrative regions. ${ }^{*} p<0.1,{ }^{* *} p<0.05,{ }^{* * *} p<0.01$. Absolute $t$ values in parentheses. 
Table 6: Robustness checks: Non-migrants, tariff decomposition, and further policy controls

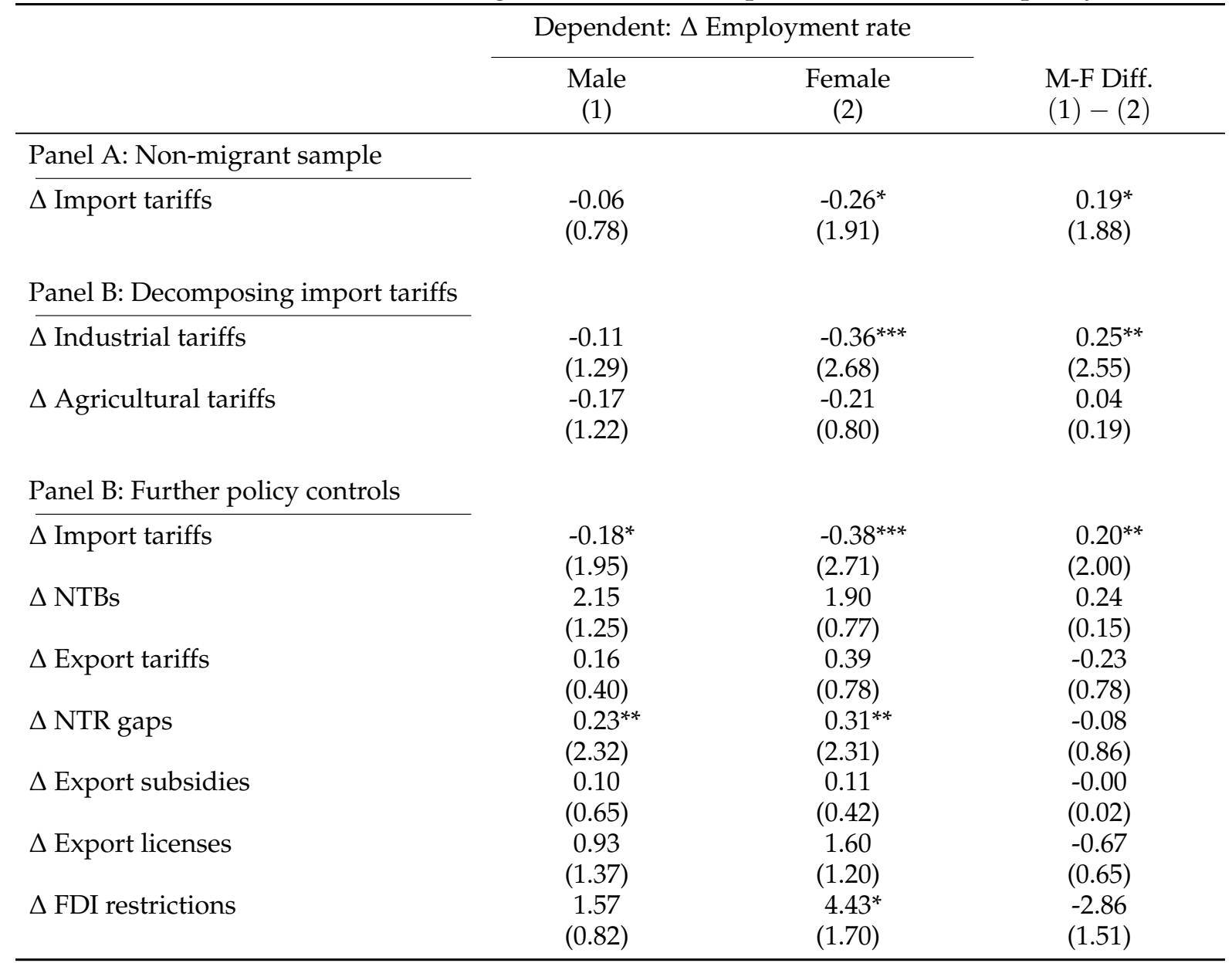

Notes: Regression results in columns (1) and (2) are estimated jointly, using robust standard errors. The last column reports the difference in coefficients between regressions for males and females (the gender employment gap). Dependent variables measure the change in the share of employment within the working age population (by gender), derived from the population censuses of 1990 and 2005. All regressions control for the 1990 level of the dependent variable, initial SOE employment shares, initial employment shares of the agriculture and tertiary sectors, and initial nightlights. Panel A only considers nonmigrants, defined as persons living within the prefecture of their original registration. Panel B decomposes tradable tariffs into agricultural and industrial tariffs. Panel $\mathrm{C}$ introduces further policy controls that measure changes in exposure to non-tariff barriers (NTBs), changes in foreign tariffs on Chinese exports (weighted by trading partners' market size), reductions in the trade policy uncertainty faced by Chinese exporters that export to the U.S. (NTR gaps), changes in average government subsidies to exporters, changes in domestic restrictions on direct exporting (export licenses), and changes in policy restrictions to FDI. $N=311$ in panels A and B; $N=306$ in panel $C$ due to missing data of further policy controls. ${ }^{*} p<0.1,{ }^{* *} p<0.05,{ }^{* * *} p<0.01$. Absolute $t$ values in parentheses. 
Table 7: Channels: Changes in the local economy and in formal industrial firms

\begin{tabular}{|c|c|c|c|c|}
\hline Measured within & $\begin{array}{l}\text { Local economy } \\
\text { (1) }\end{array}$ & $\begin{array}{l}\text { Formal industry } \\
(2)\end{array}$ & $\begin{array}{l}\text { SOEs } \\
\text { (3) }\end{array}$ & $\begin{array}{l}\text { Non-SOEs } \\
\text { (4) }\end{array}$ \\
\hline \multicolumn{5}{|c|}{ Panel A: Dependent: Expansion of female intensive sectors } \\
\hline$\Delta$ Import tariffs & $\begin{array}{l}-0.15^{* *} \\
(2.03)\end{array}$ & $\begin{array}{c}-0.10 \\
(1.25)\end{array}$ & $\begin{array}{c}-0.05 \\
(0.52)\end{array}$ & $\begin{array}{l}-0.42^{* * *} \\
(2.84)\end{array}$ \\
\hline Mean dependent (pp.) & -1.37 & -1.42 & -3.66 & -6.46 \\
\hline \multicolumn{5}{|c|}{ Panel B: Dependent: Change in sectoral gender segregation } \\
\hline$\Delta$ Import tariffs & $\begin{array}{l}0.28^{* *} \\
(2.18)\end{array}$ & $\begin{array}{c}-0.24 \\
(1.43)\end{array}$ & $\begin{array}{c}0.12 \\
(0.69)\end{array}$ & $\begin{array}{c}-0.23 \\
(1.19)\end{array}$ \\
\hline Mean dependent (pp.) & 7.42 & 1.70 & -1.10 & 0.28 \\
\hline \multicolumn{5}{|c|}{ Panel C: Dependent: Change in discrimination } \\
\hline$\Delta$ Import tariffs & & $\begin{array}{l}0.80^{* * *} \\
(3.70)\end{array}$ & $\begin{array}{c}0.42 \\
(1.21)\end{array}$ & $\begin{array}{l}0.26^{* *} \\
(2.17)\end{array}$ \\
\hline Mean dependent & & -5.79 & -8.60 & -4.24 \\
\hline \multicolumn{5}{|c|}{ Panel D: Dependent: Change in computer intensity } \\
\hline$\Delta$ Import tariffs & $\begin{array}{c}-0.04 \\
(0.93)\end{array}$ & $\begin{array}{c}-0.03 \\
(0.98)\end{array}$ & $\begin{array}{l}0.08^{* * *} \\
(2.70)\end{array}$ & $\begin{array}{l}-0.16^{* * *} \\
(5.41)\end{array}$ \\
\hline Mean dependent (pp.) & 1.77 & -0.57 & -5.71 & 5.14 \\
\hline \multicolumn{5}{|c|}{ Panel E: Dependent: Change in nightlights } \\
\hline$\Delta$ Import tariffs & $\begin{array}{l}-0.10^{* *} \\
(2.51)\end{array}$ & & & \\
\hline Mean dependent & 1.99 & & & \\
\hline
\end{tabular}

Notes: Regression results refer to the full local economy in column (1), to all formal industrial firms in column (2), to SOEs in column (3), and to non-SOEs in column (4). Column (1) is based on population census data from 1990 and 2005, columns (2) to (4) on formal firms in manufacturing and mining, derived from the industrial economic censuses of 1995 and 2004. All regressions control for the initial level of the dependent variable, initial SOE employment shares, initial employment shares of the agriculture and tertiary sectors, and initial nightlights. $N=311$ except column (4) in Panel A where $N=307$ due to missing non-SOEs in four prefectures in 1995 and Panel $C$ where $N=310$ due to missing industrial firms in one prefecture in 1995. * $p<0.1, * *$ $p<0.05,{ }^{* * *} p<0.01$. Absolute $t$ values in parentheses. 


\section{Appendix}

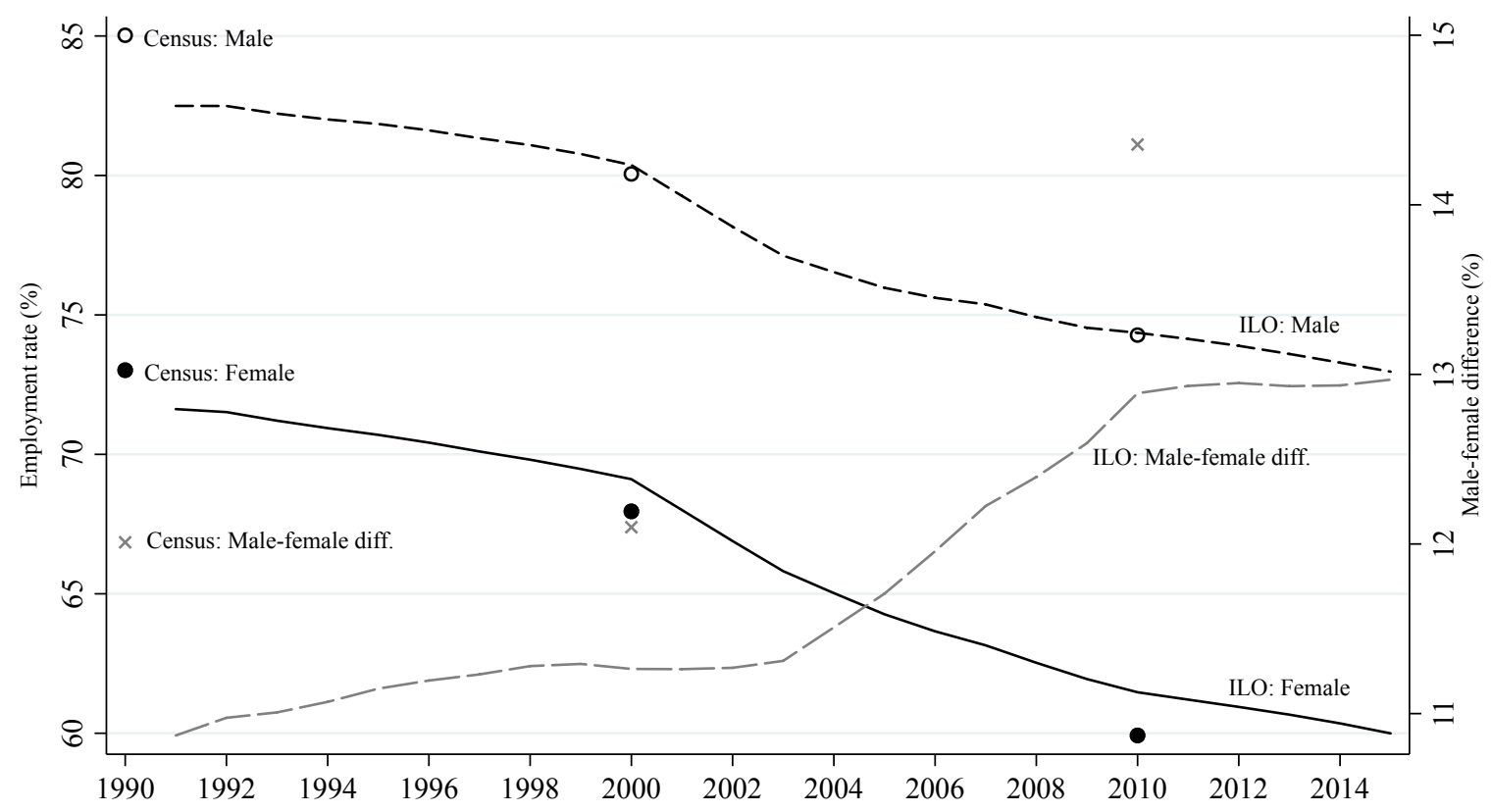

Figure A.1: Employment rate by gender in China: 1990-2015

Notes: This figure shows employment rates of youth and adults (aged 15 or above) by gender, and the difference between males and females in China across years. Lines represent employment rates as estimated by the International Labor Organization (ILO); and data markers represent employment rates from the population census waves (1990, 2000, and 2010). To make employment rates from the population census comparable to the ILO estimates, we constrain our sample to all individuals aged 15 or above. 


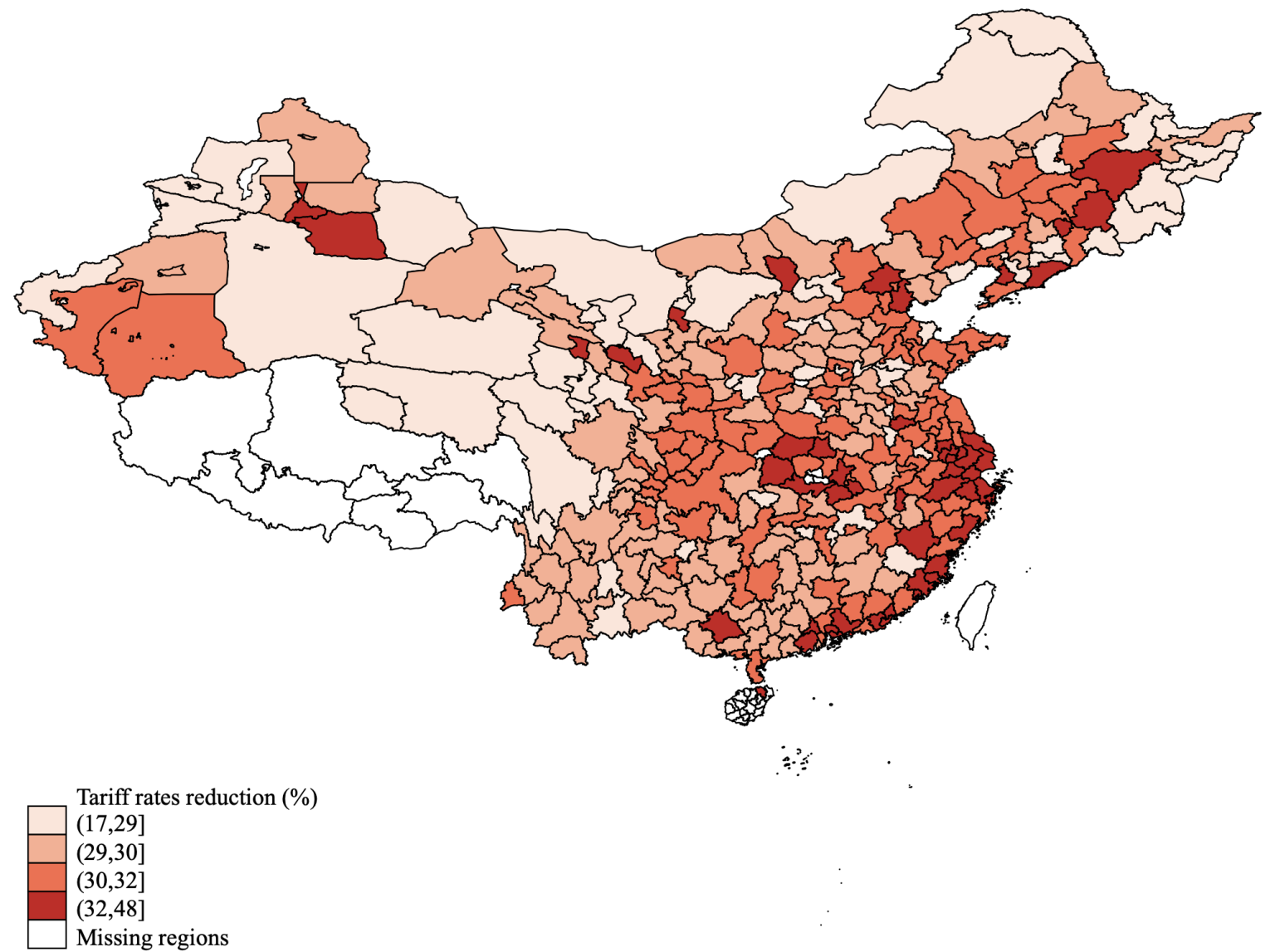

Figure A.2: Map of tariff reductions (1992-2005) across Chinese prefectures

Notes: Missing prefectures are those without data in 1990 and those with tertiary employment share higher than 75 percent. 


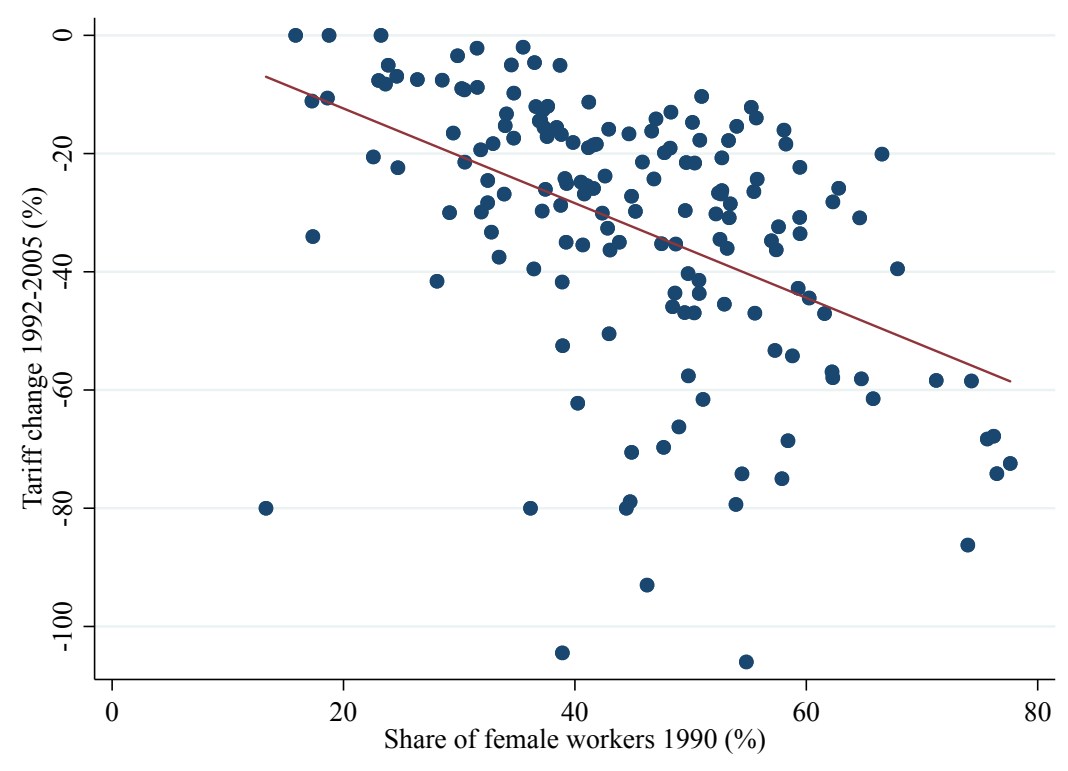

Figure A.3: Tariff declines (1992-2005) and initial female employment shares Notes: The industry codes shown in the figure are 162 three-digit CIC industries.

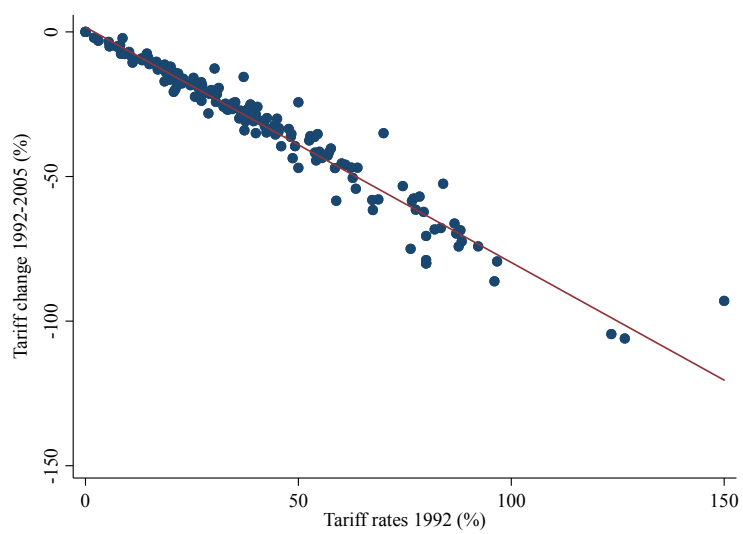

(a) Tariffs at three-digit industry level

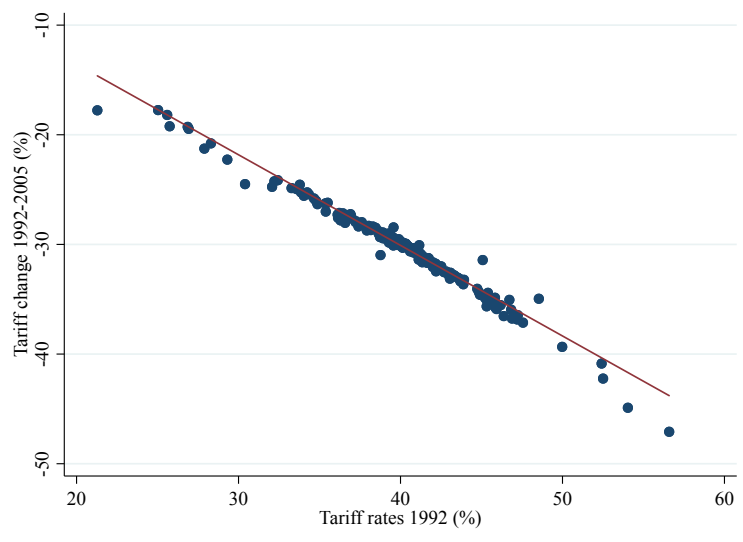

(b) Tariffs at prefecture level

Figure A.4: Import tariff declines (1992-2005) and initial tariff rates in China Notes: Prefecture-level tariff rates are calculated according to equation (1). 
Table A.1: Summary statistics of key variables

\begin{tabular}{lcccc}
\hline & Mean & S.D. & Min. & Max. \\
\hline$\Delta$ Import tariffs (pp.) & -30.09 & 3.29 & -47.09 & -17.75 \\
$\Delta$ Employment rate (pp.) & -10.24 & 6.21 & -25.48 & 13.96 \\
$\Delta$ Male employment rate (pp.) & -7.77 & 5.68 & -20.76 & 21.76 \\
$\Delta$ Female employment rate (pp.) & -12.40 & 8.58 & -32.98 & 30.58 \\
$\Delta$ Male-female employment rate difference (pp.) & 4.63 & 7.55 & -36.81 & 37.15 \\
$\Delta$ Female intensity (pp.) & -1.37 & 2.66 & -9.41 & 10.06 \\
$\Delta$ Female intensity: Formal industrial sector (pp.) & -1.42 & 3.45 & -18.89 & 8.96 \\
$\Delta$ Female intensity: SOEs (pp.) & -3.66 & 4.42 & -22.17 & 12.37 \\
$\Delta$ Female intensity: Non-SOEs (pp.) & -6.46 & 7.47 & -35.74 & 16.41 \\
$\Delta$ Sectoral gender segregation (pp.) & 7.42 & 7.89 & -16.80 & 29.34 \\
$\Delta$ Sectoral gender segregation: Formal industrial sector (pp.) & 1.70 & 6.79 & -33.99 & 18.94 \\
$\Delta$ Sectoral gender segregation: SOEs (pp.) & -1.10 & 8.91 & -33.69 & 33.35 \\
$\Delta$ Sectoral gender segregation: Non-SOEs (pp.) & 0.28 & 12.46 & -41.43 & 48.07 \\
$\Delta$ Discrimination: Formal industrial sector & -5.18 & 15.68 & -111.50 & 37.24 \\
$\Delta$ Discrimination: SOEs & -7.96 & 15.39 & -120.99 & 40.84 \\
$\Delta$ Discrimination: Non-SOEs & -3.80 & 29.90 & -226.15 & 54.87 \\
$\Delta$ Computer intensity (pp.) & 1.77 & 2.40 & -1.70 & 13.06 \\
$\Delta$ Computer intensity: Formal industrial sector (pp.) & -0.57 & 1.33 & -5.59 & 3.93 \\
$\Delta$ Computer intensity: SOEs (pp.) & -5.71 & 2.07 & -11.54 & 1.93 \\
$\Delta$ Computer intensity: Non-SOEs (pp.) & 5.14 & 1.46 & 1.02 & 11.28 \\
$\Delta$ Nightlights & 1.99 & 2.70 & -0.29 & 23.23 \\
1990 agricultural sector employment share (\%) & 68.93 & 21.18 & 3.52 & 97.42 \\
1990 tertiary sector employment share (\%) & 17.02 & 11.27 & 1.47 & 65.99 \\
1990 SOE employment share (\%) & 75.73 & 9.80 & 41.64 & 95.43 \\
1990 nightlights & 2.40 & 3.81 & 0.00 & 35.59 \\
\hline & & & & \\
\hline & & & &
\end{tabular}

Notes: Table lists selected key variables. $N=311$. Source: Authors' own calculation based on various datasources. Import tariffs at the city level are calculated according to equation (1) using industry-level tariffs from WITS and the 1990 Population Census. Employment rates by gender, female intensity and sectoral gender segregation are based on population censuses of 1990 and 2005. Computer intensity is based on sectoral computer usage, taken from the China Statistical Yearbook on Science and Technology (National Bureau of Statistics, 1991b, 1996, 2005, 2006) and sectoral employment share within cities are calculated based on the population census of 1990. Female intensity, sectoral gender segregation, computer intensity and discrimination for formal industrial sectors, SOEs, and non-SOEs are all calculated based on the industrial census of 1995 and the economic census of 2004. 1990 agricultural sector employment share and 1990 tertiary sector employment share are from the 1990 Population Census. 1990 SOE employment share is from China City Statistical Yearbook of 1991 (National Bureau of Statistics, 1991a). 1990 nightlight density is calculated based on data from NOAA. 
Table A.2: Changes of city-level import tariff exposure: 1992-2005

\begin{tabular}{lccc}
\hline Year & $1992(\%)$ & $2005(\%)$ & Reduction (pp.) \\
\hline Mean & 40.01 & 9.92 & 30.09 \\
$95 \%$ percentile & 45.87 & 10.51 & 35.51 \\
$75 \%$ percentile & 41.35 & 10.25 & 31.21 \\
$50 \%$ percentile & 40.05 & 10.17 & 29.92 \\
$25 \%$ percentile & 39.30 & 9.80 & 29.35 \\
$5 \%$ percentile & 33.78 & 8.41 & 24.95 \\
\hline
\end{tabular}

Notes: The table shows prefecture-level tariff rates at the mean and different percentiles in 1992, 2005 and the differences between the two years in percentage points.

Table A.3: Full baseline results including controls

\begin{tabular}{|c|c|c|c|}
\hline & \multicolumn{3}{|c|}{ Dependent: $\Delta$ Employment rate } \\
\hline & $\begin{array}{l}\text { All } \\
(1)\end{array}$ & $\begin{array}{l}\text { Male } \\
(2)\end{array}$ & $\begin{array}{c}\text { Female } \\
\text { (3) }\end{array}$ \\
\hline$\Delta$ Import tariffs & $\begin{array}{l}-0.22^{* *} \\
(2.32)\end{array}$ & $\begin{array}{c}-0.13 \\
(1.56)\end{array}$ & $\begin{array}{l}-0.33^{* *} \\
(2.48)\end{array}$ \\
\hline 1990 agricultural sector employment share & $\begin{array}{l}0.10^{* *} \\
(2.34)\end{array}$ & $\begin{array}{c}0.06^{*} \\
(1.75)\end{array}$ & $\begin{array}{l}0.13^{* *} \\
(2.59)\end{array}$ \\
\hline 1990 tertiary sector employment share & $\begin{array}{c}0.02 \\
(0.33)\end{array}$ & $\begin{array}{c}0.03 \\
(0.45)\end{array}$ & $\begin{array}{c}0.01 \\
(0.14)\end{array}$ \\
\hline 1990 SOE share & $\begin{array}{l}0.12^{* * *} \\
(2.96)\end{array}$ & $\begin{array}{l}0.09 * * \\
(2.53)\end{array}$ & $\begin{array}{l}0.12^{* *} \\
(2.44)\end{array}$ \\
\hline 1990 nightlights & $\begin{array}{l}0.26^{* *} \\
(2.19)\end{array}$ & $\begin{array}{l}0.26^{* * * *} \\
(2.80)\end{array}$ & $\begin{array}{c}0.23 \\
(1.63)\end{array}$ \\
\hline 1990 employment share & $\begin{array}{l}-0.54^{* * *} \\
(7.97)\end{array}$ & & \\
\hline 1990 male employment share & & $\begin{array}{l}-0.76^{* * *} \\
(9.78)\end{array}$ & \\
\hline 1990 female employment share & & & $\begin{array}{l}-0.51^{* * *} \\
(9.07)\end{array}$ \\
\hline Constant & $\begin{array}{l}13.42^{*} \\
(1.88)\end{array}$ & $\begin{array}{l}44.56^{* * *} \\
(5.29)\end{array}$ & $\begin{array}{c}0.92 \\
(0.13)\end{array}$ \\
\hline Mean dependent (pp.) & -10.24 & -7.77 & -12.40 \\
\hline $\mathrm{R}^{2}$ & 0.27 & 0.34 & 0.37 \\
\hline
\end{tabular}

Notes: Regression results are estimated using robust standard errors. Columns (2) and (3) are jointly estimated. Dependent variables measure the change in the share of employment within working-age population (in total and by gender), derived from the population censuses of 1990 and 2005. $N=311 .{ }^{*} p<0.1{ }^{* *} p<0.05,{ }^{* * *} p<0.01$. Absolute $t$ values in parentheses. 
Table A.4: Import tariffs and the expansion of education

\begin{tabular}{lccc}
\hline & \multicolumn{2}{c}{ Dependent: $\Delta$ Student share } & \\
\cline { 2 - 4 } & Male & Female & M-F Diff. \\
& $(1)$ & $(2)$ & $(1)-(2)$ \\
\hline$\Delta$ Import tariffs & $-0.32^{*}$ & $-0.41^{* *}$ & 0.08 \\
& $(1.78)$ & $(2.32)$ & $(0.85)$ \\
Mean dependent (pp.) & 21.80 & 22.12 & -0.32 \\
\hline
\end{tabular}

Notes: Regression results in columns (1) and (2) are estimated jointly, using robust standard errors. The last column reports the difference in coefficients between regressions for males and females (the gender education gap). Dependent variables measure the change in the share of students within the population aged 15 to 25 (by gender), derived from the population censuses of 1990 and 2005. All regressions control for the 1990 level of the dependent variable, initial SOE employment shares, initial employment shares of the agriculture and tertiary sectors, and initial nighlights. $N=311 .{ }^{*} p<0.1{ }^{* *} p<0.05,{ }^{* * *} p<0.01$. Absolute $t$ values in parentheses.

Table A.5: Import tariffs and individual probability of working

\begin{tabular}{lcc}
\hline & \multicolumn{2}{c}{ Dependent: Employed $(=1)$} \\
\cline { 2 - 3 } & Male & Female \\
& $(1)$ & $-0.0047^{* * *}$ \\
\hline Import tariffs & -0.0007 & $(3.27)$ \\
\hline Mean dependent & $(0.89)$ & 0.78 \\
Observations & 0.86 & $3,982,426$ \\
$\mathrm{R}^{2}$ & $4,188,056$ & 0.22 \\
\hline
\end{tabular}

Notes: Regression results in columns (1) and (2) are estimated jointly, using robust standard errors clustered at the prefecturecity level. The dependent variables are indicator variables equal to one when an individual works. All specifications control for individual characteristics, initial prefecture-characteristic specific trends, prefecture fixed effects, and a time effect. Individual characteristics include age, age squared, education level, hukou type, marital status, ethnicity, household size, as well as indicators for household heads and migrant status. Prefecture-level initial characteristics of 1990 include SOE employment shares, employment shares of the agricultural and tertiary sectors, nightlight density, and initial male/female employment rates; all are interacted with a year indicator. ${ }^{*} p<0.1,{ }^{* *} p<0.05,{ }^{* * *} p<0.01$. Absolute $t$ values in parentheses. 
Table A.6: Controlling for potential channels

\begin{tabular}{|c|c|c|c|c|c|c|}
\hline & \multicolumn{6}{|c|}{ Dependent: $\Delta$ Employment rate } \\
\hline & \multicolumn{3}{|c|}{ Panel A: Full sample } & \multicolumn{3}{|c|}{ Panel B: Non-SOEs } \\
\hline & Male & Female & $\mathrm{M}-\mathrm{F}$ & Male & Female & $\mathrm{M}-\mathrm{F}$ \\
\hline & $(1)$ & $(2)$ & $\begin{array}{c}\text { Diff. } \\
(1)-(2)\end{array}$ & (3) & $(4)$ & $\begin{array}{c}\text { Diff. } \\
(3)-(4)\end{array}$ \\
\hline$\Delta$ Import tariffs & $\begin{array}{l}-0.18^{* *} \\
(1.98)\end{array}$ & $\begin{array}{l}-0.49^{* * *} \\
(3.25)\end{array}$ & $\begin{array}{l}0.31^{* * *} \\
(2.77)\end{array}$ & $\begin{array}{c}0.32 \\
(1.62)\end{array}$ & $\begin{array}{l}-0.04 \\
(0.39)\end{array}$ & $\begin{array}{l}0.37^{* *} \\
(2.48)\end{array}$ \\
\hline$\Delta$ Share of female intensive sectors & $\begin{array}{l}0.36^{* * *} \\
(3.03)\end{array}$ & $\begin{array}{l}0.91^{* * *} \\
(4.95)\end{array}$ & $\begin{array}{l}-0.56^{* * *} \\
(3.95)\end{array}$ & $\begin{array}{l}-0.06^{*} \\
(1.81)\end{array}$ & $\begin{array}{c}0.03 \\
(0.98)\end{array}$ & $\begin{array}{l}-0.09^{* * *} \\
(3.96)\end{array}$ \\
\hline$\Delta$ Sectoral gender segregation & $\begin{array}{c}0.02 \\
(0.60)\end{array}$ & $\begin{array}{l}-0.17^{* * *} \\
(2.74)\end{array}$ & $\begin{array}{l}0.20^{* * *} \\
(4.22)\end{array}$ & $\begin{array}{l}-0.05^{* *} \\
(2.26)\end{array}$ & $\begin{array}{l}-0.04^{* *} \\
(2.46)\end{array}$ & $\begin{array}{l}-0.01 \\
(0.64)\end{array}$ \\
\hline$\Delta$ Gender discrimination & $\begin{array}{l}0.05^{* *} \\
(2.13)\end{array}$ & $\begin{array}{c}0.02 \\
(0.76)\end{array}$ & $\begin{array}{c}0.03 \\
(1.34)\end{array}$ & $\begin{array}{l}0.04^{* * *} \\
(2.63)\end{array}$ & $\begin{array}{l}0.02^{* *} \\
(2.26)\end{array}$ & $\begin{array}{c}0.01 \\
(1.37)\end{array}$ \\
\hline$\Delta$ Computer intensity & $\begin{array}{c}0.22 \\
(1.30)\end{array}$ & $\begin{array}{c}0.05 \\
(0.22)\end{array}$ & $\begin{array}{c}0.17 \\
(0.99)\end{array}$ & $\begin{array}{l}1.07^{* * *} \\
(4.41)\end{array}$ & $\begin{array}{l}0.85^{* * *} \\
(4.08)\end{array}$ & $\begin{array}{c}0.22 \\
(1.59)\end{array}$ \\
\hline$\Delta$ Nightlights & $\begin{array}{l}0.61^{* * *} \\
(3.28)\end{array}$ & $\begin{array}{l}0.71^{* * *} \\
(3.05)\end{array}$ & $\begin{array}{l}-0.10 \\
(0.58)\end{array}$ & $\begin{array}{l}1.48^{* * *} \\
(5.07)\end{array}$ & $\begin{array}{l}1.74^{* * *} \\
(5.26)\end{array}$ & $\begin{array}{l}-0.25 \\
(1.55)\end{array}$ \\
\hline
\end{tabular}

Notes: Regression results in columns (1) and (2) are estimated jointly, using robust standard errors. The last column of each Panel reports the difference in coefficients between regressions for males and females (the gender employment gap). Dependent variables measure the change in the share of employment within the working-age population (by gender), derived from the population censuses of 1990 and 2005. All regressions control for the 1990 level of the dependent variable, initial SOE employment shares, initial employment shares of the agriculture and tertiary sectors, and initial nightlights. $N=310$ for Panel A and $N=307$ for Panel B. ${ }^{*} p<0.1,{ }^{* *} p<0.05,{ }^{* * *} p<0.01$. Absolute $t$ values in parentheses. 


\section{ONLINE APPENDIX}

\section{A Data generation and description of variables}

Estimation sample Our main regression results are based on 311 prefectures of China. We first concord the 1990 prefecture codes with the 2005 ones by combining prefectures in 2005 back to 1990 for split prefectures. This yields 322 prefectures. We exclude seven Tibetan prefectures due to missing data of key variables, and further exclude four prefectures with higher than 75 percent tertiary employment in 1990.

We concord prefecture city codes of 1995 and 2004 with those in the population census, and obtain a final sample of 311 prefectures.

Measuring prefecture-level import tariff rates Our prefecture-level import tariff rates are calculated in two steps. First, we calculate tariff rates at the 1990 sector level. We obtained data on effectively applied tariff rates at HS 6-digit level in the years 1992 (the earliest available year) and 2005 from the World Integrated Trade Solution (WITS) database. We first concord the product-level tariff rates to 4-digit Chinese Industry Classification (CIC) 2002 version using the concordance table provided by Brandt et al. (2017). ${ }^{13}$ Tariff rates at the 4-digit CIC level are calculated as the simple average across all products within industries. We then map tariff data at the 2002 CIC level to the 1990 3-digit sector level using our own concordance table. Again, tariff rates at the 3-digit sector level are simple averages within sectors. In the second step, we calculate prefecture-level tariff rates according to equation (1), which combines sectoral employment shares of tradable sectors within prefectures in 1990 and time-variant sector-level tariffs.

In our robustness checks, we decompose tariff rates into industrial tariffs and agricultural tariffs by using employment shares of industrial and agricultural sectors separately.

Measuring prefecture-level employment rates We measure employment rates in 1990 and 2005 based on the 1 percent random sample of the 1990 population census obtained from IPUMS-International (Minnesota Population Center, 2019) and the $2005 \mathrm{mini}$ population census obtained from National Bureau of Statistics. Overall and genderspecific employment rates at the prefecture level are calculated by dividing the total number of employed by the size of the working-age population (in total and by gender). Prefecture-level employment and population are aggregated using sampling weights. Considering that the official retirement age is 50 years old for females and 60 years old for males in China, we constrain working-age population to those aged between 15 and 50. Employment rates by age group and by skill level are calculated similarly. We consider workers as high-skilled if they have completed at least high school (upper secondary education).

Employment rates in 1982 are aggregated from the population census of 1982, obtained from IPUMS-International as well. Due to changes in administrative codes, we can only

\footnotetext{
${ }^{13}$ The concordance table provided by Brandt et al. (2017) has only manufacturing industries. We manually generate a concordance table for agriculture and mining industries.
} 
identify 277 consistent prefectures with the 1990 codes.

Employment rates of formal industrial (mining and manufacturing) sectors in 1995 and 2004 are calculated based on the 1995 industrial census and the 2004 economic census data, both obtained from National Bureau of Statistics. We aggregate the total number of workers reported by each firm to the prefecture level (in total and by gender) and divide it by the size of the working-age population (again aged 15-50). Working-age population of 1995 is from the National 1\% Population Sample Survey Statistical Book (1995). As working-age population at the prefecture level is not available for 2004, we use data from the 2005 mini population census instead. Employment rates of SOEs and private firms are calculated based on firm ownership information. SOEs include both state-owned enterprises and collective-owned enterprises. Private firms include domestic private firms and foreign-invested firms.

Prefecture-level initial conditions 1990 employment shares of the agricultural and tertiary sectors over total prefectural employment are calculated from the 1990 population census. 1990 SOE employment share denotes the share of SOE employment in total prefectural urban employment. The data is obtained from China City Statistical Yearbook (National Bureau of Statistics, 1991a).

Nightlight data are derived from the National Oceanic and Atmospheric Administration (NOAA). Prefecture-level nightlights are calculated as the simple average of all pixel values within the boundary of each prefecture in 1990 and 2005.

Additional policy related control variables In our robustness checks, we control for a large set of measures for the regional exposure to trade related policies, including NTBs, export tariffs, NTR tariff gaps, government subsidy to exporters, export licensing requirements, and FDI restrictions. Industry-level NTBs and FDI restrictions are from Brandt et al. (2017). We employ a similar approach to equation (1) and calculate regional exposure to NTBs and FDI restrictions by weighting industry-level NTBs and FDI restrictions using the initial level of sectoral employment share within prefectures as weights.

We collect product-level export tariffs by country from the WITS database and construct product-level export tariffs as the weighted average of foreign tariff rates using the relative economic size of each potential trading partner as weights:

$$
\operatorname{ExpTariff}_{s t}=\sum_{n=1}^{N} \frac{G D P_{n t}}{\sum_{n=1}^{N} G D P_{n t}} T_{\text {snt }},
$$

where $T_{\text {snt }}$ is the tariff imposed on China's export product $s$ by country $n$ in year $t$. We weight national tariff lines by the relative share of each country $n$ in year $t$ in world GDP, $G D P_{n t} / \sum_{n=1}^{N} G D P_{n t}$, to approximate the export market potential of various trading partners. We then map the HS 6-digit product-level export tariff rates to the 1990 3-digit sectoral level and calculate prefecture-level tariff rates following equation (1).

Prefecture-level measures of NTR tariff gap, government subsidy to exporters, and export licensing requirements are obtained from Facchini et al. (2019) which are available for 1999 
and 2005. Given that 1999 is still before China's WTO accession, we use these short-term changes as proxies for long-run changes for the purpose of robustness checks. We have data for 306 prefectures.

Measuring channel variables Expansion of female-intensive industries $\left(F I_{p t}\right)$ and sectoral gender segregation $\left(S I_{p t}\right)$ are calculated using equation (3) and (4) using the 1990 and 2005 population census waves, and the 1995 industrial census as well as the 2004 economic census. Since four prefectures had no private firms in 1995, we are only able to calculate $F I_{p t}$ and $S I_{p t}$ for the private sector for 307 prefectures.

We estimate the sectoral level discrimination index following equation (5) using the 1995 and 2004 firm census data, and then compute the local degree of discrimination by using time-variant industrial employment shares within each prefecture as weights following equation (6). Since one prefecture had no industrial firms in 1995, the discrimination measure is only available for 310 prefectures.

The local computer intensity measure is computed in two steps. We first calculate the share of computers within the total value of machinery for medium and large industrial firms within two-digit sectors, obtained from the China Statistical Yearbook on Science and Technology (National Bureau of Statistics, 1991b, 1996, 2005, 2006). Then we use the population census waves in 1990 and 2005, as well as the firm census waves in 1995 and 2004 to measure the relative importance of each two-digit sector within each prefecture and compute a prefecture-level index of computer intensity following equation (7).

Lastly, we use prefecture-level nightlights as a proxy for local average income (derived from NOAA). 